\title{
O "MEDITERRÂNEO" SAARIANO E AS CARAVANAS DO OURO (III).
}

(Conclusão).

\section{CAPitulo VI}

\section{"ILHAS" DE SEDENTARIEDADE NO "MAR ARENOSO" E ESCALAS DE CARAVANAS NO "LITORAL" SUDANO-SAARIANO.}

Entre o Maghrebe e o Grande Deserto intercala-se, como vimos, desde Não, no Atlântico, a Oeste, até Gabés, no Mediterrâneo, a Levante, uma faixa de planaltos pedregosos (hammadas) e dunas de areia (ergs) entrecortados de oásis de tamareiras ao longo do curso dos uedes ou junto a fontes artesianas. Para o Sul alonga-se agora o Sáara, a pobreza extrema de vegetação e vida animal, a ausência quase completa de povoamento humano.

Todavia, vamos descobrir no deserto maior variedade de condições do que seria de supor, deparamos com pequenas "ilhas" de sedentariedade perdidas na vastiđão imensa. Ao longo do Atlântico, a pesca permite o estabelecimento de reduzidos grupos humanos em aldeias de palhotas (399); a influência oceânica 'cria uma estreita banda litoral de pastos, aproveitada por cabildos de pastores nômades e semi-sedentários. Daqui para o interior, percorrem-se mais de $2.000 \mathrm{~km}$. sôbre um tabuleiro uniforme, quase desprovido de elevações montanhosas, e isto numa largura também superior a $1.000 \mathrm{~km}$. Em todo o caso, o Sáara ocidental é menos hostil à vida do que o deserto líbico ou os tanezruft que rodeiam os maciços centrais. A monotonia de altitude é quebrada precisamente no centro do Sáara por formações montanhosas, chegando o ponto mais alto a atingir $3.006 \mathrm{~m}$. (Tahate, no Ahoggar). Como era de prever, estas serras - Adrar dos Iforas, Air e Ahoggar - beneficiam de chuvas de que carecem os desertos em volta, e portanto

(399). - Crônica da Guiné, cap. LXXVI. 
revestem-se de manto vegetal que com a sua aridez contrasta. $O$ Sáara meridional, à medida que se aproxima dos rios Senegal e Níger, forma transição do deserto para a savana, da imensidão sem chuvas para os países de chuvas de estio. Neste Sahel, "litoral" do sertão sudanês face ao "mar arenoso", nasceram naturalmente aglomerados que vivem do tráfico caravaneiro.

\section{1. - A Serra Bafor (Adrar Mauritânio) e a escala comercial de Uadam.}

Para Oeste da sebkha de Igilde estende-se uma planície sem areia nem pedra nem terra, tôda sòmente em seixinhos (400), quer dizer, um erǵ, na designação indígena que os geógrafos adotam como têrmo técnico. Dura esta paisagem cinco a seis jornadas, até - Adrar Suttufe a Poente. Esta serra de Suttufe, não longe do litoral atlântico (entre $15^{\circ}$ e $16^{\circ}$ de longitude ocidental), a Nordeste do Cabo Branco,

"é uma região alta granítica; alguns dos cumes estão a 120 metros acima da planície, e o maciço pode atingir 400 a 500 metros; é um centro hidrográfico importante, com bons pastos" (401).

Combina evidentemente as vantagens da altitude com as da presença oceânica. Na paisagem pintam-se mesmo algumas matas, e os serranos pastoreiam quer camelos, quer cabras e carneiros, quer até bois.

Para meio dia da planície de pequenos seixos, entre o Adrar Suttufe a Noroeste e o Adrar Tmar a Sudeste, e dêste até perto do litoral de Arguim a Poente, espraiam-se dunas de areia, o deserto de Aquixar (402). Não é só, contudo, pelo Oeste e Noroeste que o Adrar Tmar está rodeado de formações arenosas, é também por Leste e Sul.

Inteirramente paleozóico, assente num solo cristalino e metamórfico, o Adrar, composto de um complexo de base greso-xistocalcária, sôbre o qual repousam as camadas de grés e grés quartzítico (403), ergue-se no meio de uma depressão ocupada por sebkhas e dunas.

A serra recorta-se como uma sucessão de degraus e patamares, na direção do paralelo. Passado o primeiro patamar de grés, onde se encontra o palmar de Azogui, galga-se uma arriba gresífero-

\footnotetext{
(400). - Valetim Fernandes, fol. 71 v. (pág. 49). Exemplo frisante da exatidão das observações quatrocentistas e quinhentistas portuguêsas.

(401) . - Bernard, pág. 384

(402). - V. Fernandes, fol. 71 v. (pág. 49). Cf. Bernard, pág. 364, e as cartas atuais.

(403). - Monod, Sur la constitution Eéologique de I'Adrar mauritanien.
} 
xisto-calcária de uma centena de metros mas ultrapassando esta altitude em certos pontos, e chega-se a um planalto gresífero-calcário suavemente inclinado para Leste, em cuja depressão fica Atar. Uma nova falésia, de xistos e grés polícromos, cuja altitude atinge $500 \mathrm{~m}$., serve de degrau ao planalto (dhar) de Chingueti, todo de grés: a serra culmina a $715 \mathrm{~m}$., em Zorga (404).

Não suscita a mínima dúvida a identificação com o Adrar Tmar (ou mauritânio), da Serra Bafor nomeada na relação de Diogo Gomes-Behaim, no Esmeraldo e na descrição de Valentim Fernandes.

Esta última fonte pinta-a minuciosamente e com exatidão surpreendente. Assim, notou o aspecto de arriba que apresenta de um dos lados:

"Seys legoas da pedra Schelud esta huma serra muy alta chamada Baffor, a qual serra tē 18 legoas em côprido e he fecta como muro propriamète da banda do norte que he contra os desertos e he tã alta esta serra que parece chegar aos çeos. Esta serra nō tem senõ tres portaes de subir per ella, e assi parece cousa èpossiuel, porè passã camellos" (fol. 72 v., p. 50 ).

Mas se nesta parte do quadro ainda há a descontar o exagêro na apreciação da altitude, no resto é inteiramente exato.

$\mathrm{Na}$ serra Bafor contam-se catorze leitos de ribeiras em que nunca corre água senão em tempo de trovoadas, as quais são de fevereiro até maio.

“Estas ribeyras sõ grãdes e largas è quãtidade quãdo choue e vam todas dar em hum deserto grãde de area, e ahy se somem propriamëte como aqui no mar e esto no tempo sóo que choue. E nesta terra nõ choue se nõ cõ trouoadas. E acabadas as trouoadas e chuyua lozo as ribeyras som secas que nõ pareçe gota dagoa".

Cavando no leito a sêco destas ribeiras apenas um côvado $(66 \mathrm{~cm})$ de profundidade, acha-se logo água (405) - informação quatrocentista que concorda plenamente com os dados da geografia recente. Estes vales estreitos revestem-se de tamarais (406).

Mas nenhuma verdura de ervas atapeta os leitos dos uedes. As formações botânicas consistem, além das tamareiras, de "Árvores de goma" (407). Monod identificou-as com a Acacia Raddiana Savi e com a Acacia Seyal Delille, únicas que hoje existem à latitude de Arguim; não se trataria da Acacia senegal Lineu, a verda-

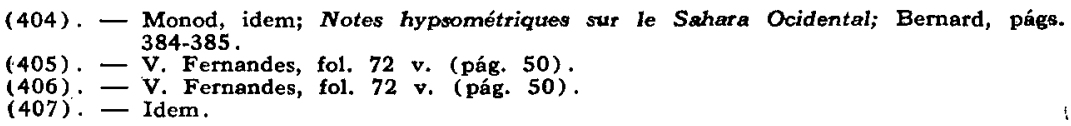


deira árvore da goma, pois não se encontra atualmente no Adrar (408). Em nova exploração, em 1948, encontrou, porém, pés de Acacia Senegal, sem por isso modificar a sua identificação:

"Il me paraît cependant très peu vraisemblable que cette espèce ait été tellement plus abondante au XVe siècle qu'elle ait pu attirer l'attention d'un voyageur qui ne pouvait certes avoir aucun scrupule à appeler "gommier" tous les Accacias, d'autant plus que ceux de l'Adrar donnent tous' de la gomme (non "arabique")".

Uma vez que a verdadeira árvore da goma existe ainda hoje na serra Bafor, e atendendo a que pela feitoria de Arguim se exportou, nos séculos XV e XVI, muita goma, não é disparatado admitir uma regressão desta formação botânica, devida precisamente à sua exploração. As correções, com base na geografia atual, dos dados das fontes antigas revelam-se freqüentemente aventurosas, porque pesquisas ulteriores mostram que houvera enganos, e o meio fito-zoológico pode ter mudado, até pela ação do homem.

Os serranos semeiam trigo no meio dos palmares, embora em pequena quantidade (409). Fazem também sementeiras de cevada e de milho de Guiné (o milho zaburro), mas em proporções ainda menores.

"Semeã em a metade darea onde Deos nunca da herua, e fazē huma çerca de rama de tamaraes em derrador quãto cada hum tem semeado. E na meetade do semeado fazē hum chaffariz, e armã lhe huma picota pera tirar agoa cõ cubo, cõ a qual agoa regã ho semeado e ahy se cria muyto alto e muy fremoso e assy toda outra cousa que queré semear como alhenã e outras heruas a nós ignotas. E a çeyffa do dito semeado fazē no março" (410).

Criavam-se algumas cabras, consoante nos informam o Esmeraldo e Leão-o-Africano, e talvez também pequeno número de carneiros (só a primeira destas fontes os aponta). Em todo o caso, a criação de gado devia ter bem diminuta importância, pois a pormenorizada descrição de Valentim Fernandes não a menciona sequer. De maior importância era a caça, que se fazia com rêde; apanhavam-se assim antas e emas (411).

O nível técnico era muito elementar, como se deduz da ausência de aparelhos de moagem e da rudimentariedade da cozinha. Desconheciam-se as atafonas, azenhas e mesmo os pilóes braçais. Para reduzir os grãos à farinha colocam-se sôbre uma pedra levemente côncava e trituram-se com outra pedra a que se impri-

(408). - Description de la côte d'Afrique, pág. 165 .

(409). - Idem; Esmeraldo, I, cap. 25.

(410): - V. Fernandes, fol. 73 v. (pág. 50)

(411). - Leão-o-Africano, II, 96; V. Fernandes, fol. 74 (pág. 51 ). 
me um movimento de vai-e-vem, esfregando o trigo entre ambas. Não separam o farelo nem peneiram a farinha.

A base da alimentação e o seu elemento quase único, são as tâmaras (412), cuja produção não é aliás abundante, embora as chegassem a qualificar de

$$
\text { "as melhores do mundo" (V. Fernandes). }
$$

Mas também se comia, embora sem regularidade, carne de anta e de ema (413); talvez ainda, com menor freqüência, carne de cabra e de carneiro, a darmos crédito ao Esmeraldo, que Leãoo-Africano não confirma pois declara que as cabras são criadas só para aproveitar o leite.

"Em esta serra de Baffor ha tamãnhos ratos acerca como coelhos e tã gordos cõ rabo de coelho tem a cabeça grãde e as orelhas cortas e comẽ nos, e som muy gostosos. E chamã nos alffart".

Th. Monod identifica êstes "ratos" com o damão (Rocavia sp.), visto que no Adrar não se encontram roedores daquela estatura.

Como a produção de tâmaras não se fazia com fartura e contudo entravam em percentagem fortíssima na alimentação, davam-se com frequiência crises de escassez. Acresce que por vêzes os nômadas salteavam os palmares, destruindo as tâmaras antes do tempo ou roubando-as, pelo que aos serranos falecia êsse mantimento. A situação tornava-se a tal ponto angustiosa que se caía na antropofagia. Declara-o peremptòriamente Valentim Fernandes

"Em esta serra as vezes comē huns a outros, ou a qualquer de fora se ho pode apanhar... e matãdo se huns cõ outros comē suas carnes";

afirma-o igualmente o Esmeraldo:

"Muitas cousas leixamos de dizer do deserto de Arguim e da serra de Baffor, honde comem os homës" (cap. 26 do liv. I).

Não se acreditava nestas informações, mas passou a dar-se-lhes crédito desde que se soube que durante a crise de fome de 1904 se praticaram no Adrar atos de canibalismo (414).

Em compensação, em dias de festa, geralmente nas recepções de hóspedes, a ementa incluia pão de trigo e até carne de camelo. O trigo é então moido pelo processo acima descrito,

\footnotetext{
(412). - V. Fernandes, fol. 73 v. ("Ellle se mantem de tamaras", "nõ tem outro (413). - Leão-o-Africano, II, 95-96.

(414). - Movod, pág. 156.
} 


\begin{abstract}
"e amassã hum pouco em paães e metē no em huma fỏrnalha em que tambem metē alguã pequena de carne de camelo ou outra carne alguma e ho çarrã e ho leixã coser etc." (415) .
\end{abstract}

Conquanto a antropofagia só devesse praticar-se em crises excepcionalmente graves de escassez, os mercadores evitavam freqüentar a serra e passavam prudentemente a 15 ou 20 léguas, com pavor do canibalismo. A sua prudência ia ao ponto de não acenderem fogueiras nem de noite nem de dia, para não serem avistados pelos serranos, de modo que tinham de comer a carne crua.

"A carne de ema pisã cõ ho mesmo seuo della e assy a comē sem mais ser assada nem cosida";

comiam também carne de camelo e de anta (416).

$O$ vestuário dos serranos era muito pobre, andavam quase nus. Pobre, aliás era todo o seu nível de vida (Leão-o-Africano, II 95-96).

No Adrar Mauritânio existiriam no fim do século XV, segundo a Descrição de Valentim Fernandes, as quatro cidades de Oadem, Oulili, Schinguete e Tyrnjgui, e a vila de Fara; o Esmeraldo enumera uma "vila", Audem, e "três lugares pequenos", Singuyty, 'Tynyguuhy e Marzy. E' natural que a povoação Marzy de Duarte Pacheco se identifique com a Oulili de Valentim Fernandes. Parece, assim, que já não existiria então Azogui, fundada no século XI (El-Békri, p. 316), a $15 \mathrm{~km}$. da atual Atar e reduzida hoje a palmar sem quaisquer habitações. Abeir, que remontava ao século VIII, desaparecera também, esta no decurso de Quatrocentos, substituída por Chinguetti, que é nesta centúria que nasce, gerando por seu turno Atar na éra de Quinhentos ou de Seiscentos (417). Houve quem identificasse a Oulili da Descrição com a Aulil dos geógrafos muçulmanos, o que não parece de aceitar, pois a última se situava no litoral atlântico; Marquart aventou a hipótese, que se afigura plausível, de que houve uma migração dos Beni Goddala da costa para o interior, desaparecendo assim a Aulil e surgindo a Oulili (418). E não seria de aproximar o topônimo Azogui, que se lê em El-Békri, do etnônimo Ezarziguy, que o Esmeraldo menciona como o dos habitantes de Uadam? Tratar-se-ia de duas povoações povoadas pelo mesmo grupo étnico, ou de transferência de população de um local para outro. Segundo Monod, os Ezarziguy são provàvelmente os atuais Akhzazir ou Aghzazir, tribo de

\footnotetext{
(415). - V. Fernandes, fol. 73 v. (págs. 50-51); Cf. Esmeraldo, I, cap. 25: "E esta jente se mantem de tamaras e d'algum pouco triguo que semeam nos palmares e de carne de cabras e carneiros".

(416). - v. Fernandes, fol. 73 v. $e^{-74}$ (pág. 51).

(417). - La Chapelle.

(418). - Monod, pág. 155.
} 
magarefes e vendedores de sal. Não é, aliás, disparatado supor que Uadam nasceu como mercado do sal de Igilde.

Uadam data do século XII ou do XIV (La Chapelle). Na outra margem do ribeiro que por ela passa, a um tiro de besta, existira outra "cidade", Bym, de que no fim de Quatrocentos ainda se viam as ruínas de

$$
\text { "grãdes edificios e paaços"; }
$$

uma cheia torrencial destruira-a (419), o que é vulgar no Sáara; no cabeço de Lekser Th. Monod descobriu ruínas de construções que devem corresponder à antiga Bym. De Ulili (a 2 tiros de besta de Uadam) a Chinguetti seriam 4 léguas, desta a Tinigui 6 , ficando a vila de Fara a 2 léguas de Tinigui; isto segundo os cômputos da Descrição, que quanto à primeira distância peca muito por defeito; o Esmeraldo aproxima-se mais da verdade, ao dar Chinguetti a 15 cu 20 léguas de Uadam (fica a cêrca de $88 \mathrm{~km}$.). Tinigui situava-se $45 \mathrm{~km}$. a Nordeste de Chinguetti (Monod).

Uadam contava 300 (Esmeraldo) ou 400 (V. Fernandes) vizinhos. Era a principal "cidade" do Adrar, e importante centro mercantil. Com efeito, era aqui o mercado do sal de Igilde donde seguia por Tichite e Ualata, para o Sudão (420). Porque escápula do sal, havia em Uadam

"grãde trato d'ouro que ahy trazem de Guinee por terra" (Esmeraldo, cap. 25 do liv.'I).

Por ambas as razões, e pela sua posição geográfica, Uadam constituia escala das caravanas que traficavam entre a Barbaria e Tombuctu e outras cidades negras (421). Aquêle mercado do Adrar começou a decair no alvorecer do século XVI, com o início da decadência do tráfico caravaneiro devido ao estabelecimento dos resgates no litoral sudanês (V. Fernandes).

A Crônica da Gưiné diz (cap. LXXVI) que Uadam é o único lugar cercado na Terra dos Negros; todavia Cadamosto afirma que não tem qualquer cêrca, e que está sujeito aos alarves, isto é, aos nômades (422). Segundo Leão-o-Africano, os moradores de Uadam mal ousam sair da aldeia devido à hostilidade dos vizinhos - o que torna plausível a existência de uma cinta de defesa contra os serranos de Bafor.

Mas as outras "cidades" também não se fechavam ao exterior; tanto em Chinguetti como em Tinigui e Marzy havia trato

(419). - V. Fernandes, fol. 73 (pág. 50).

(420). - V. Fernandes, fol. 74 (pág. 51): "Oadem he huma çidade de 400 vezinhos e he a principal desta serra de Baffor pello grande tracto porque hescapola de todo ho sal que vem de Ygild e dhy levã o sal os mercadores a huma cidada chamada "Tisthid".

(421). - Cadamosto, Nav. Primeira, cap. IX.

(422). - Idem. 
de ouro. De igual modo que Uadam, êstes três povoados estavam sujeitos aos alarves (423). Todos os habitantes da serra e dos aglomerados urbanos seguiam a religião mafometana (424).

$$
\text { 2. - O "Iitoral" (Sahe1) sudano-saariano. }
$$

Entre o deserto saariano, ao Norte, e as savanas e florestasparques sudanesas, a Meio Dia, interpõe-se uma faixa de transição que se desenrola segundo os paralelos, desde o Oceano ao lago Tchade. Setentrionalmente desenha-a uma linha traçada da latitude do Cabo Mirik, a Poente, à latitude de $15^{\circ}$ por alturas do Tchade, a Levante, baixando primeiro de modo a passar não longe do cotovelo do Níger $\left(17^{\circ}\right.$ de latitude $\left.\mathrm{N}\right)$, para subir em seguida e incluir o Adrar dos Iforas e o Air como promontórios setentrionais, e de novo descer. Meridionalmente, esta faixa termina cêrca do paralelo $16^{\circ}$ junto ao Atlântico e cêrca do paralelo $14^{\circ}$ a Leste. Quer o rio Senegal quer o rio Níger, nos cotovelos que formam, o primeiro no curso terminal e o segundo no curso médio, atravessam esta faixa; todavia a presença, a oeste, dos cursos fluviais, bem como, a Leste, do lago Tchade, e as características do povoamento e modo de vida levam a integrar as áreas adjjacentes no mundo guineense.

As chuvas estivais próprias do Sudão, vêem ainda fertilizar esta extensa mas estreita banda, no entanto com maior irregularidade e em menor volume, pelo que não é possível uma sólida agricultura com alicerce no seu aproveitamento. E' todavia de tal monção sudanesa que depende indiscutivelmente a flora, e se ela faltasse estas regiões transformar-se-iam em ténéré - áridos desertos. Do ponto de vista botânico, caracterizam o Sahel formações densas de Commiphora africana, Cenchrus biflorus, Cadaba farinosa e Cadaba glandolosa, Boscia Senegalensis, Blepharis linearifolia, Bouchea marrubiifolia, Commelina Forshalei, Geigeria alata, Euphorbia balsamifera e Acacia Senegal (ou Verek). Além desta árvore da goma, a verdadeira, que vimos surgir no Adrar, e perto do Atlântico se mostra nas imediações de Nuakchott, espraiando-se igualmente entre Arauane e Tombuctu, bem como, a Leste, desde Zinder ao lago Tchade, na paisagem saheliana entram ainda as outras "árvores da goma", quer a Acacia Seyal, pertencente ao complexo sudano-decanês, quer a Acacia Raddiana (ou Tottilis), elemento de ligação dêsse complexo com o saaro-sindês. No Adrar dos Iforas e no Air é freqüente a Accacia arabica. Sempre que há água a pequena profundidade, encontra-se a palmeira do

(423). - Esmeraldo, I, cap. 25.

(424). - V. Fernandes, fol. 74 (pág. 51). 
Egito (Hyphaene thebaica), que falta todavia no Tagama, ao passo que o Panicum turgidum atapeta as dunas mortas (425).

Não apresenta, evidentemente, a faixa saheliana uniformidade de paisagem. Quem, entrando do Sáara, avança em direção às grandes savanas e florestas, vai vendo pouco a pouco o deserto restringir-se a vegetação variegar-se e toucar áreas cada vez maiores. Monod foi, por isso, levado a distinguir duas sub-faixas, divididas, grosso modo, por um paralelo, uma saheliano-saariana e outra saheliano-sudanesa. O limite setentrional do Sahel pode ser definido, segundo Kilian, por uma planta parasita da Accacia Raddiana e que o é também da Accacia Seyal: o Loranthus pentagonia $D$. C. é a guloseima que se dá ao mehair para conquistar as suas boas graças, e o seu alimento preferido quando não há árvores verdes; para viver exige abundância e profundidade de água no solo (426).

"Em suma, o que domina nesta zona é o complexo bosque e estepe de mimóseas; a autêntica savana só excepcionalmente aparece" (427).

A fauna sudanesa também penetra nesta zona de transição. O leão habita o Air e faz incursões ao Adrar dos Iforas durante a estação chuvosa; em ambos se vêem por vêzes macacos e são freqüentes os zebús (bois com bossas), que chegam a mostrar-se mais ao Norte, no Ahoggar. Nas margens do Níger e do lago Tchade acontece encontrar-se a girafa (428). Mas o que, do ponto de vista da fauna, mostra ao viajante que saiu do Sáara e entrou no Sahel, é o encôntro da Gazella rufifrons, da Testudo calcarata, do Corvus albus, dos cinocéfalos e do orietéropo (429).

Denominaram os indígenas esta faixa Sahel, que quer dizer "litoral": e de fato, que é ela, senão o "litoral" do Sudão a cujos pés vem morrer o "mar arenoso e pedregoso" que é o Sáara?

\section{3. - As cidades do Sahel Ocidental: Tichite, Ualata, Atauane.}

$\mathrm{Na}$ rota das caravanas que ligam Uadam a Ualata, $376 \mathrm{~km}$. a Sueste da primeira e $264 \mathrm{~km}$. a Noroeste da segunda, entre $9^{\circ}$ e $9^{\circ} 30^{\prime}$ de longitude ocidental e em cêrca de $19^{\circ}$ de latitude setentrional, o tráfico caravaneiro criou a "cidade" de Tichite, que nas primeiras décadas do século XVI contava uns 400 fogos. Para o Sul estende-se uma formação de dunas. No pequeno território da povoação cultiva-se a cevada e o milho zaburro e cria-se um pe-

(425). - Monod, Notes botaniques. Bernard, págs. 319-320; cf. pág. 286.

(426). - Travaux de'l'L. de R. S., III, págs. 80-81.

(427) - Bernard, pág. 320 .

(428). - Bernard, págs. 320-321.

(429). - Monod, Notes botaniques. 
queno número de ovelhas. O palmar fornece as tâmaras, tão importantes na alimentação. O nível de vida é miserável, a pobre$z a$, quinhão de todos. Mas se a existência é dura, devido às condições naturais agrestes, a verdade é que

"Tichite é um centro mercantil. Grande parte da população consagra-se ao comércio, indo levar as mercadorias a Guzula, no Sul marroquino, e à Terra dos Negros; por isso metade dos habitantes nunca se encontra na cidade" $(430)$.

Tichite é escápula do sal que por Uadam vem de Igilde e se escoa para Ualata; fica a sete jornadas daquela e a oito desta. Os mercadores de Ualata é aqui que se encontram com os de Uadam para comprar o sal (431). Existia uma pequena indústria local de fiação e tecelagem de lã, exercida pelo sexo feminino (432); não parece que chegasse para alimentar qualquer comércio, devia estar limitada pela fraca criação de gado miúdo.

Em 1224, as famílias ricas Soninké e os mercadores árabes e berberes de Gana, para escaparem às exações do domínio sosso que há anos se exercia na cidade, emigram para o Sáara e vão fundar Ualata (Biru em língua sarakolé), cujo desenvolvimento dá um novo salto a partir de 1240 com o eclipse de Gana devido à sua conquista pelo rei malinké Sundiata (433). Em meados do século XIV Ualata era governada por um lugar-tenente (farba) do imperador de Mali. Em fins do século XV viveu algum tempo independente sob o duplo senhorio de um chefe branco e de um chefe negro. Mas no tempo de Leão-o-Africano foi conquistada pelo senhor de Tombuctu e ficou a pagar-lhe tributo. Está agora muito decaída: de "cidade mui grande" (V. Fernandes) reduziu-se a três aldeias grandes e algumas aldeolas (Leão-o-Africano); o declínio deve-se à concorrência de Tombuctu como terminus das caravanas vindas da Barbaria.

A população compõe-se de negros e berberes, mas conta também judeus, que são muito ricos por exercerem as profissões de mercador, ourives e joalheiro. E' natural que fôsse forte a percentagem dos mestiços. No tempo de Ibne Batuta a maioria da população pertencia à tribo berbere dos Messufa. Exceptuado o elemento judaico, todos seguem, contudo, a religião de Mafamede. Ualata está na linha de contacto de dois mundos: o mundo negro e o mundo berbere-árabe ("é a primeira localidade do país dos negros" para quem vem do deserto, diz Ibne Batuta; "parte com terra de negros", diz V. Fernandes), os nômadas do deserto e os agri-

(430). - Leão-o-Africano, II, 95.

(431): 二 V. Fernandes, fol. 74, (pág. 51 ).

(432). - Leão-o-Africano, II, 95 .

(433). - Delafosse, Haut-Sénégal-Níger, pág. 55 do t. II. 
cultores sedentários das savanas. E' difícil apreciar o grau de cultura e civilização. Ibne Batuta queixou-se da pouca consideração que os negros, que então dominavam na cidade (eram negros o governador e o inspetor geral), mostravam pelos brancos mas encontrou aqui um juiz e um jurisconsulto e professor. Leão-o-Africano, porém, declara que não há em Ualata juízes nem cortesãos. A díferença atesta o declínio no intervalo. Segundo o geógrafo quinhentista, a maneira de viver não difere da dos vizinhos que habitam no deserto.

$\mathrm{Na}$ região reina calor excessivo. Mas sob as areias formam-se toalhas de água, depositadas pelas chuvas, o que permite a cultura do solo (434). Assim vicejam alguns palmares de pequenas tamareiras, a cuja sombra crescem melões e melancias (435). Produz-se milho zaburro, conquanto em pequena quantidade (436). Carne, apenas de carneiro: Ibne Batuta diz que há em abundância, ao passo que Leão-o-Africano declara que a carestia é permanente. O nível de vida não é brilhante. Uma refeição de gala, oferecida pelo inspetor da cidade ao viajante trecentista, consistiu de milho triturado, misturado com mel e leite azedo; a comida foi servida em cabaças cortadas em forma de malga.

No tempo de esplendor (século XIV) a população trajava belo vestuário, importando os tecidos do Egito. A influência do trajo azenegue mantinha-se ainda nos alvores de quinhentos, pois Leão-o-Africano viu os homens de rosto tapado.

A família messufita apresentava certas peculiaridades que im1.ressionaram Ibne Batuta. As mulheres não cobriam o rosto com véu nem se sentiam obrigadas a manifestar pudor. As relações sexuais extra-matrimoniais eram correntes. Mas o mais importante é que a genealogia se estabelece matrilinearmente; o nome herdase do tio materno; os bens transmitem-se não aos filhos do morto mas aos sobrinhos filhos da irmã.

A vida da cidade é essencialmente comercial. E' que Ualata é um dos extremos meridionais da rota caravaneira que vem de Sidjilmessa passando por Tagaza (Ibne Batuta), e além disso é escápula de todo o sal de Igilde que lhe chega pela via de Uadam e Tichite, e que distribui quer aos reinos do Senegal quer a Tombuctu (V. Fernandes). Na própria cidade há uma classe importante de mercadores, que freqüentam, por exemplo, o mercado do sal em Tichite. Mas estão cá estabelecidos também negociantes de fora parte. $E^{\prime}$ assim que o viajante trecentista esteve hospedado em casa de um marroquino natural de Salé. Por essa mesma data, cinco irmãos de Tremecem tinham fundado uma associação

(434). - Ibne Batuta, IV, 387.

(435). - Idem; Leão-o-Africano, II, págs. 146-147.

(436): - Leão-o-Africano, id. 
comercial, na base de igual partilha de lucros; dois ficam na cidade natal para expedir para o Sul as mercadorias provenientes da Europa; um terceiro fixa-se em Sidjilmessa para transmitir aos outros quatro irmãos as cotações das mercadorias; os dois últimos estabelecem-se em Ualata para comprarem o marfim e o ouro sudaneses a trôco dos artigos recebidos do Norte e os enviarem para - Maghrebe.

Â chegada da caravana do Norte a Ualata as mercadorias são descarregadas numa vasta praça, onde ficam à guarda dos negros, e os mercadores vão cumprimentar o governador, que os recebe sentado num tapete debaixo de uma espécie de alpendre; por trás alinham-se, em pé, os grandes da cidade, à frente estão os guardas armados com lanças e arcos (437).

Vimos acima que Ualata decaiu no século $\mathrm{XV}$, sem dúvida devido à deslocação para Leste da pista de caravanas: em vez de infletirem, a partir de Tagaza, para Sudoeste, em direção a Ualata, passaram a dirigir-se quase em linha reta sôbre Tombuctu. E' natural que esta via mais curta fôsse seguida já antes do século XII, mas o tráfego por ela intensificou-se depois da fundação de Tombuctu (início do século XII) e sobretudo no decurso de Quatrocentos. Esta rota segue, ao Sul da atual Taudeni, a depressão por onde outrora corria e se perdia o rio Níger antes de, por captação de outro curso, formar o cotovelo e correr para Sueste; acabava então em Ful el Alba. Neste fundo de laguna surgiu, no século XI ou XII, a povoação de Arauane, cêrca de $250 \mathrm{~km}$. ao N. de Tombuctu, num local onde as caravanas faziam aguada.

\section{4. - A serra dos Iforas e a cidade de Tadmekkete.}

O Sáara central caracteriza-se pelo violento contraste entre os tanezruft, imensas extensões absolutamente desérticas, e os planaltos e maciços montanhosos onde a vida viceja graças às chuvas da monção sudanesa. Estes focos de sedentariedade adquirem extraordinária importância como escalas na travessia do Sudão para o

- litoral mediterrâneo e como pontos de apôio dos nômades.

Tôda a metade meridional da planície de Tamesna e os vales setentrionais do Adrar dos Iforas e do Air constituem o que Maire e Volkansky batizaram de "savanas sub-sahelianas das pastagens de verão"; na nomenclatura de Monod, Sahel sahariano. Paisagem de "árvores e palha". As chuvas caem de maio a setembro; e em 37 anos, só se registaram 4 de sêca. O arvoredo, numeroso, compōe-se de duas das Acaciae - a Seyal Del, e a Raddiana Savi -, Maeura crassifolia Forsk, Boscia senegalensis Lamk, Ba-

(437). - Ibne Batuta, IV, pág. 385. 
lanites aegyptiaca Del.; os vales do Air contam ainda com a Salvadora persica $L$, a palmeira do Egito, e a Grewia Tenax. Na estepe vivem gramíneas permanentes, como o Panicum turgidum, - Lasiurus hirsutus e o Andropogon proximus, mas os tornados de verão fazem nascer gramíneas temporárias, que se desẹnvolvem ràpidamente e ràpidamente secam. Os vales formam assim as pastagens saarianas de inverno que dominam sempre.

Para Meio Dia do uede Agadez, estendem-se, do Air meridional ao Sul do Adrar dos Iforas, as "savanas sahelianas" - o Sahel sudanês. Se certas características se mantêm, como a formação de pastagens temporárias no estio com os tornados, as gramíneas vivazes abundam, e os bosques, que incluem agora a Commiphora africana e novas "árvores da goma", reverdecem em profusão mesmo fora dos leitos dos uedes (438).

O Adrar dos Iforas é um planalto de cêrca de $800 \mathrm{~m}$. de altitude, com algumas partes graníticas alteando-se a $1.000 \mathrm{~m}$., rodeado a tôda volta, excepto numa estreita banda a Sudoeste, por desertos completamente estéreis e inumanos. A fertil pianície de escoamento e dispersão de águas de Tilemsi, numa depressão orientada pelo meridiano, articula a serra dos Iforas à bacia nigeriana.

"Comparado ao Ahoggar, o Adrar é uma região relativamente rica; os jardins que aqui se encontram são mais exíguos de que os daquele, a criação do boi de bossa, do zebú, faz-se em larga escala; o gado é numeroso e é bem alimentado nas vastas planícies de aluviões férteis, atapetadas de gramíneas, com algumas árvores, em tôrno das quais se erguem blocos de rochas escalvadas de aspecto francamente saariano".

Por isso na estação desfavorável os Hoggar vêm com o gađo refugiar-se no Adrar (439).

No Sudoeste do planalto, a $320 \mathrm{~km}$. a N-NE. de Gao, quer dizer, junto à planície de Tilemsi, que é o caminho natural para o Níger, surgiu na alta Idade Média, se não mesmo antes da éra cristã (Delafosse), uma cidade dos berberes Saghmara (do ramo Lamta) embuçados como os outros que povoavam o Adrar e como êles islamizados já no século XI: Tadmekkete, em árabe Es-Suk. De Gana (Kumbi, a SW. de Nema) aqui havia relações regulares de caravanas, que seguiam parte do curso do Níger e depois atravessavam o deserto; por seu turno, de Tadmekkete parte outra rota para Kairuam, na Ifríquia (Tunísia), a qual passa por Uargla e Castilia; Tadmekkete estava também em relações com Gadamés. A cidade é grande, e tem melhores edifícios do que

(438) . - Sôbre êstes dois parágrafos, Maire e Volkansky, Le passage..:

(439): - Bernard, págs. 364-365. 
Gana e Gao. O seu comércio devia ser intenso: como moeda, corriam dinares de ouro puro (440). Por aqui se escoava para Gao o sal da mina de Tutek, junto ao Ahoggar (El-Békri).

A alimentação compõe-se de carne, de leite, de um grão selvagem (Cenckrus biflorus, o chaskanit ou cram-cram, como identificou Monod) e sorgo, êste cereal importado da Terra dos $\mathrm{Ne}$ gros (441).

O vestuário é de tecidos de algodão tintos de vermelho. $\mathrm{O}$ xeque usa um turbante vermelho, túnica amarela e calças azuis (442).

\section{5. - A serra do Aït e a cidade de Agadez.}

O Aïr, com um comprimento de $250 \mathrm{~km}$. e largura máxima de $75 \mathrm{~km}$., é um planalto com a altitude de $800 \mathrm{~m}$., sôbre o qual se erguem maciços vulcânicos dos quais o mais elevado culmina a $1.800 \mathrm{~m}$. Rodeado a Leste e a Norte por tanezruft, domina a Poente a vasta planície de Talak, muito rica de água e pastagens; a Oeste desta é que se espraia novo tanezruft, até o sopé do Adrar dos Iforas. Nesta planície uma depressão de $200 \mathrm{~km}$, por vêzes inundada, recebe as águas dos koris, os ribeiros que atravessam o Air de Leste para Oeste e chegam a correr três a quatro vêzes por ano. Estes ribeiros

"são muito mais vivos do que os outros uedes saarianos; em alguns dêstes koris a vegetação é quase florestal. Na maioria dos casos o kori está colerto de um tapete de gramineas com algumas árvores isoladas".

Mas fora dos vales o solo apresenta-se geralmente escalvado, só com raras acácias (443).

Como o Adrar dos Iforas, o Air é habitado por nômadas e sedentários embuçados. Mas o seu primeiro povoamento foi de negros Haússa: Haússa de Daura, os mais puros, e seguidamente Haússa do Gober (os mais setentrionais), com influências coptas e já infiltrações Sanhadja. Conhecido então por Asben, que significa "a Terra dos Negros", o Air tinha como capital T'in Shaman ou Asaman, a $2 \mathrm{~km}$. da futura Agadez:* Ora o topônimo relaciona-se, quanto à raiz, com Nasamànés, o etnônimo da tribo do Grande Sirte citada por Heródoto. Mas desde 800 os "embuçados" assenhorearam-se do Kanem e do Bornu, dominando as suas populações negras; e de 850 a 1.086 a dinastia targui Dugurva reinou sôbre ambas as regiões. No século XI a invasão hilaliana provo-

(440). - E1 Békri.

(441). - Idem; Massalik, pág. 94.

(442). - Idem.

(443). - Este parágrafo resume Bernard, págs. 365-366 319. 
cou sucessivos redemoinhos no Sáara central, até bem ao Sul. Uma dinastia muçulmana, a dos Beni Hume, negróides com aliança tebu, destrona e substitui a dinastia dos Dugurva. Os "embuçados" vêmse assim forçados a emigrar, indo instalar-se com os antigos povoadores, assimilação que se efetua principalmente entre os sedentários, mantendo-se os grupos nômadas com maior pureza de sangue. No fim do século XII e comêço do século XIII, nova vaga targui, a dos $\mathrm{Kel}$ Geres, vindos do Norte, vem subergir o Air ocidental (444).

As relações com o mundo sudanês continuaram íntimas: de lá vinham, como para os outros oásis saarianos, escravos para constituirem a mão-de-obra rural. Na primeira metade do século XIV o império mandinga, que para Ocidente ocupava Tichite, Ualata e Arauane, englobou uma parte do Air (Agadez) e do Adrar dos Iforas (Tadmekkete), bem como a mina de cobre do Takedda, entre ambos. Todavia, em $1310-1350$ os reinos de Tadmekkete e do Air tinham conseguido a independência ou só reconheciam uma vaga suzerania (Massalik, p. 94). Durante o século XVI - Air pagou tributo ao reino negro de Kebbi (a Sudoeste de Sokoto) (445), só com um curto intervalo de dois anos - 1515-1517 - em que esteve sob o senhorio sonrai, pagando 150.000 ducados de páreas (446).

E' do pastoreio que vivem os habitantes do Air (447), conquanto não ignorem a agricultura. Por isso as suas habitações são de ramos ou esteiras, e desmontam-nas e transportam-nas a dorso de boi (448). Mas é claro que nas cidades, centros comerciais, há casas de pedra ou de adôbes.

Ao lado do pastoreio, a atividade econômica característica do Air é o trato do sal e dos escravos. Os tuaregue formam enormes caravanas que atravessam o tanezruft que se espraia a Levante e vão ao oásis de Kaùar buscar o sal de Bilma, que depois distribuem ao mundo negro - reinos entre o Tchade e o Níger. Por outro lado, adquirem escravos no Suđão e escoam-nos para os oásis setentrionais e para a Tripolitânia e Tunísia. O Air é escala na rota que liga a Ifríquia, por Gadamés, ao reino haússa.

Não admira, por estas razões, que no Air se formasse um empório mercantil à semelhança de Tadmekkete no Adrar dos Iforas. Assim surgiu Agadez no decurso do século XV, cêrca de 1460, situada no extremo meridional. A cidade, cingida de muralhas, compunha-se de bons edifícios com arquitetura semelhante à das

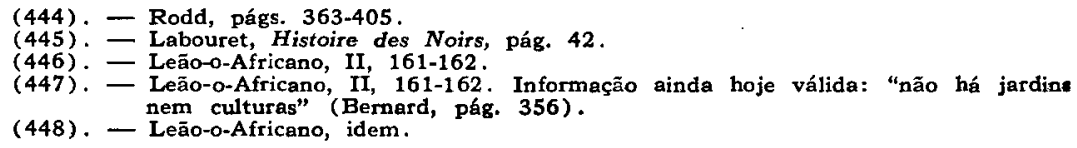


cidades da Barbaria. O Rei vivia num palácio cuntuoso. A população, que no século XVI não devia contar menos de 30.000 habitantes (Rodd) consistia principalmente de mercadores, e além disso de artífices, da guarda real e do funcionalismo.

A percentagem de escravos, de origem negra, é muito elevada. Cada mercador possui grande número para lhe servirem de escolta na travessia dos desertos, sobretudo do que se estende entre o Air e o lago Tchade, pois os nômades não perdem ensejo de saltear as caravanas. Mas os escravos, além da labuta pesada da carga e descarga dos camelos e bois, e de outros trabalhos, ajudam o dono nos negócios. Mais ainda, quando o mercador chega a qualquer aglomerado, retém consigo uma guarda de 10 ou 20 para o escoltar e velar pelas mercadorias, e põe os restantes a trabalhar como artífices para ganhar dinheiro.

Como armamento, estas escoltas dispunham de espadas, dardos, arcos e setas. Pouco antes de 1517 começaram a manejar também a besta, arma que lhes veio do Mediterrâneo e lhes garantia superioridade militar sôbre os adversários.

A cidade de Agadez é então como capital do Air. O poder está nas mãos dos nômadas tuaregues, como é constante no Sáara. O rei é, portanto, um chefe embuçado, e rodeia-se de uma guarda real forte composta também de embuçados. Os direitos pagos pelos mercadores estrangeiros em trânsito e os impostos locais rendem ao fisco régio farta receita - o que explica que pudesse pagar ao imperador de Gao a soma de $\mathbf{1 5 0 . 0 0 0}$ ducados anualmente no embora curto intervalo em que esteve sob a sua suzerania (449). Aliás o tributo ao rei de Kebbi, pago até 1600 , não devia ser muito inferior.

(449). - Leão-o-Africano, II, 160-162. 


\title{
CAPfTUlo VII
}

\author{
AS CARAVANAS DO OURO \\ 1. - As pistas das cáfilas e as correntes de trocas: \\ o problema e as fontes.
}

A Antigüidade conheceu quando muito três ligações entre o mundo mediterrâneo e o Sudão. A existência de uma delas, a via maritima a ligar as feitorias estabelecidas ao longo das costas saariana e guineense, afigura-se assaz problemática; seja como fôr, não sobreviveu ao eclipse de Cartago. A ligação cuja realidade se afirma insintestável tinha os seus pontos de partida nas cidades da Tripolitânia e da Tunísia atual, donde se dirigia quer a Gadamés e Ghate, quer ao Fezzam, para se internar em seguida pelo Tassili dos Ajjer e Ahoggar, bifurcando-se para o Adrar dos Iforas, por um lado, e Air, pelo outro, até o mundo negro. A terceira rota, que se infere do alinhamento das estações rupestres e da prosperidade de Lixus (quando a não explicamos pelo tráfico marítimo), atravessava o Sáara sub-atlântico; não parece que uma circulação intensa a animasse, se de fato alguma vez foi uma via de comunicação mercantil e não apenas de deslocamento migratório. No conjunto, quanto às vias terrestres, há que sublinhar que o tráfico não estava aparelhado com o mais poderoso meio de locomoção não mecânico para 'o deserto: $o$ dromedário.

Tôda a novidade dêste Mediterrâneo saariano que surge no século VIII reside aí, na criação de tôda uma teia de caravanas de"senhando as suas pistas através do Sáara central e ocidental. Infelizmente, só a partir do meio do século $X$ é que podemos fazer o levantamento do seu traçado e seguir a sua evolução. Durante três séculos, a 100 anos de intervalo entre si, Iline Háucal, El-Békri e Edrici permitem-nos cartografar as pistas e apreender as suas mudanças. O século XIII e o primeiro quartel do século XIV formam um espaço em branco. A partir de 1340, com o Massalik, Ibne Batuta, Ibne Khaldun e as cartas catalãs, no século seguinte e no início do século XVI graças às fontes portuguêsas, à cartda de Malfante, às descrições de Cà da Mosto e de João Rodrigues e à "suma" geográfi'ca de Leão-o-Africano, volta a ser possivel determinar os principais itinerários e algumas das suas vicissitudes. 
2. - As pistas das cáfilas e as correntes de trocas através do Sáara atlântico, de Tacrur, Audaghosté e Ghana aos oásis sul-marroquinos.

Entre o arco da costa atlântica e outro arco grosseiramente concêntrico passando por Uadam, o Sáara estreita-se no seu comprimento meridiano. Do Sul, o Sahel e a zona sub-saariana avançam até a latitude do Cabo Mirik ( $\left.19^{\circ} 22^{\prime}\right)$; ao Norte o uede Não, o uede Dar'a e a Seguiet el-Hamra conquistam à desolação largas áreas de vida. Através do Sáara atlântico encontram-se fàcilmente pastagens e pontos de água. Eis, portanto, um domínio de predileção para os nômadas, que não deixam de o percorrer em todos os sentidos e durante percursos enormes, com as suas manadas de camelos e bois, e os seus rebanhos de carneiros e cabras. Via de comunicação natural entre o Senegal e o Sus.

Além disso, ao longo do litoral, berberes azenegues que se consagram à pesca à rêde conseguem viver em sedentariedade muito precária em pobres aldeolas. Os nômades compram-lhes ou roubam-lhes o pescado sêco ao sol. Desde Biach $\left(16^{\circ} 40^{\prime}\right)$ ao Meio Dia, até Marsa $\left(18^{\circ} 20^{\prime}\right)$ e, mais ao Norte, nas imediações da Ponta de Tofia (cabo Mirik), o mar depositou outrora, e deposita ainda, quando uma pluviosidade excepcional ajuda, camadas de sal nas bacias desenhadas pelas dunas que as eufórbias e a Tamarix atapetam. Algumas destas sebkhas fornecem até o sal em barras, tão cômodo de transportar a dorso de camelos. Desde o século $\mathrm{X}$ o mais tardar, caravanas em proveniência da cidade berbere de Audaghoste atravessam o Tagante e vêm a Aulil, isto é, à região de Trarza, carregar sal para o levar aos mercados negros. Esta corrente de trocas através do Sahel e da zona sub-saariana mantevese no decurso dos séculos seguintes, e pode-se documentar a sua persistência à volta de 1500 . No século XII, as pirogas de tucurores e jalofos desciam o rio Senegal, desde as cidades da Barisa, Silla e Tacum até a foz, subiam ao longo da costa, carregavam as barras de sal nas sebkhas em exploração, e regressavam pelo mesmo caminho a vendê-lo a tôdas as aldeias e cidades de negros (450). Ignoramos em que data esta estrada fluvial-marítima deixou de ser freqüentada, parece que no século $\mathrm{XV}$ as pirogas já não se aventuravam a fazer esta viagem. Do litoral, os cameleiros Beni Goddala e os barqueiros negros levavam igualmente âmbar cinzento, e nas florestas de Acacia verek do Dahar e do Iguidi saheliano (não confundir com o erg Iguidi) abasteciam-se de goma. Trazidas pa- 
ras as cidades do Alto Senegal, para Audaghoste (no Rkiz (451) e Ghana (no Uagadu), estas duas mercadorias eram em parte reexportadas com destino a Marrocos.

Outras caravanas transportavam diretamente o âmbar cinzento e a goma das regióes de Trarza e de Arguim para os mercados do Sus, do Dar'a e do Tafilelte. Nos pontos de partida, ao longo do Baixo e do Médio Senegal, compravam também ouro e escravos. De Aulil levavam um mês e meio a dois meses para chegar quer a Nul quer a Sidjilmessa. Deviam acompanhar de bastante perto a costa até as vizinhanças de Arguim, encontrando todos os dias poços na areia - hassi, de uma profundidade de $1,5 \mathrm{~m}$. a $4 \mathrm{~m}$.; depois afastavam-se talve $z$ uma ou duas jornadas para o interior para aproveitarem uma linha de poços furados na rocha a uma profundidade de mais de $20 \mathrm{~m}$. e distantes uns dos outros 2 ou 3 jornadas de marcha; iam dar perto do Rio do Ouro, donde passavam à Seghiet el-Hamra e finalmente a Dar'a. Não é fácil averiguar se estas caravanas, de que El-Békri fala explicitamente, continuaram com regularidade, ou se as trocas passaram a ser efetuadas só graças às deambulações das tribos nômades. A primeira hipótese enquadra-se muito melhor com o que sabemos dos mercados do uede Não, do uede Messa e do Sus, assim como com as informações das fontes portuguêsas.

Através do Sáara atlântico, uma outra rota se estabeleceu desde cêdo - desde o século VIII o mais tardar -, a qual une o Rkiz, o Tagante e o Senegal aos oásis do Sul de Marrocos. Os mercadores de Sidjilmessa encaminhavam-se pelo país de Dar'a para a vertente meridional do Anti-Atlas, onde se encontravam com os mercadores vindos do país do açúcar e dos metais (Sus); neste ponto de encôntro, favorecido pela existência de uma mina de prata, uma cidade nasceu, Tamedelte, "fundada" por Abd Allah Ibne Idris Ibne Idris. Posteriormente, os ksur de Ofram suplantá-la-ão. A viagem do Tafilelte aqui durava 11 dias, e de Igli (a cidade que precedeu Tarudante) a Tamedelte, contavam-se 6 . A caravana metia-se a caminho, e logo a uma jornada de marcha podia refrescar-se no poço dos cameleiros, o primeiro dos poços furados por iniciativa de Abd er-Tahman Ibne Habib, o conquistador árabe, durante o segundo quartel do século VIII. Transpõe-se em seguida o Djebel Bani, cujo solo pedregoso faz sofrer as patas dos camelos. Eram necessários ainda 10 dias para chegar ao sopé ocidental do Adrar mauritânio, nó de tôdas as pistas que se dirigem para o Sudão; de caminho teve-se a sorte de matar a sêde em 6 po-

\footnotetext{
(451). - Localizava-se Audaghoste no Tagante mas as pesquisas arqueológicas de Mauny, ainda inéditas, levam a localizá-la no pequeno maciço do Rkiz. Aquêle arqueólogo teve a amabilidade de nos comunicar, em março de 1949: "Je viens de visiter ses ruines (Tegdaoust) encoré très visibles: rues, constructions à l'angle droit. Cet emplacement serait à fouiller".
} 
ços e fontes, a etapa mais longa sem água foi de 4 dias. O Adrar era um ninho de salteadores, e continuou a sê-lo até o século XVI; os nômades Guzula e Lamta vinham aqui pilhar as cáfilas. De novo em marcha, caminhava-se durante cinco jornadas sôbre dunas de areia - um erg - e uma semana depois começavam as precauções contra os salteadores negros que andam à estreita. Do Adrar a Audaghoste a caravana fazia aguada por cinco vêzes em poços cuja distância oscila entre uma e três jornadas. Os que partiam de Sidjilmessa chegavam à vista da capital dos "embuçados" do Rkiz e do Tagante um mês e meio a dois meses após a partida. Esta pista continuava a ser freqüentada durante a segunda metade do século XII, porque é a ela que Ibne Saíde parece referir-se num texto transmitido por Abulfeda.

A principal escala desta pista era a Serra Bafor (o Adrar mauritânio), ou antes, a sua periferia. Desde o século VIII existia aí, perto da futura Chinguetti, a aldeia de Abeïr, mas como a rota se deslocou um pouco para Oeste, foi substituída no princípio do século XI pela cidade de Azogui. A formação do império almorávida teceu entre o Senegal e o Maghrebe el-Aksa novos laços; de oravante entre as cidades do reino tucoror - Silla, Tacrur - e os oásis do Sul marroquino as cáfilas circulam regularmente, seguindo uma rota que em 25 dias conduz a Azogui, onde se bifurca, para ir dar quer a Sidjilmessa, a Nordeste, em 13 dias, quer a Nul, a Noroeste, num pouco mais de uma semana. De Ghana, também se vinha pelo Tagante a Azogui, para seguir depois para o Norte uma das duas pistas que acabamos de traçar. Poços assaz numerosos balizavam o caminho tanto do Senegal como do Uagadu à cidade berbere do Adrar, cuja função e fortuna the serão arrebatados nos séculos XIII e XIV por Uadam, quando as rotas se deslocarem fortemente para Leste.

Se compararmos a descrição de Ibne Háucal com as de E1Békri e de Edrici, algumas diferenças ressaltam. Ibne Háucal descreve só duas pistas caravaneiras no Sáara ocidental: a pista Audaghoste, Aulil, Sidjilmessa, quer dizer costeira, e a pista mais direta entre aquêles dois extremos, pela Serra Bafor, menos longa cêrca de meio mês. Haverá que concluir que Ghana só tinha relações com Marrocos por intermédio da capital berbere do Rkiz e do Tagante? Que os mercadores do Sus tinham de passar pelo Tafilelte para negociar com a Guiné? A esta pergunta responderemos resolutamente não; as caravanas de Sidjilmessa torcem caminho precisamente no sentido do Anti-Atlas, seria por conseguinte bem pouco natural que as cáfilas do Sus fôssem até o Tafilelte para depois recuarem. Ã primeira pergunta é muito difícil responder.

Em Ibne Háucal, não há dúvida: nenhuma referência a rotas que atravessem o Sáara a Leste do Adrar mauritânio e a Oeste 
do Adrar dos Iforas e do Ahoggár. Equivalerá êste silêncio a uma prova de inexistência? Seria bem temerário concluí-lo. Decerto, o Sáara atlântico é muito mais fácil de atravessar, e não é inverossímil que os mercadores em viagem para Ghana desviassem a princípio o caminho para passarem por Azogui, ou até Audaghoste. Já, todavia, um século mais tarde, El-Békri descreve uma pista que liga o uede Dar'a a Ghana sem, ao que parece, cortar o Tagante. Da capital do império sarakollé, as cáfilas iam à serra Bafor, passando primeiro nas imediações da futura Tichite e internando-se em seguida numa "solidão desolada" - um erg; balisada por assaz numerosos poços (distantes em média de duas jornadas), a via do Adrar a Dar'a atravessava o Sáara atlântico, sobrepondo-se à que de Azogui se encaminhava a Nul ou Sidjilmessa. No século XIII as caravanas freqüentavam ainda a mesma pista, cuja escala essencial continuava a ser Azogui, e nos arredores desta cidade berbere os Lamta espiavam sempre, prontos a pilhar as mercadorias e a cativar os mercadores. Cêrca de 1500 o têrmo meridional já não era Ghana mas sim Ualata; no entanto, as cáfilas seguiam ainda o mesmo itinerário por Tichite, serra Bafor e uede Dar'a até o Sus (Leão-o-Africano).

De Aghmate, das cidades do Sus, de Nul, das cidades do AntiAtlas e do "país do anil" (Dar’a) e de Sidjilmessa, as cáfilas de camelos levavam cobre e panos, bijuteria de vidro, de conchas e de pedras, cauris e perfumes, drogas e tâmaras. Com êstes produtos, os mercadores do Norte compravam em Ghana, Audaghoste e Tacrur ouro, escravos, goma, âmbar cinzento. O ouro forneciamno os mineiros do Bambuk, Gangaram, Mandinga e Buré. Os berberes, os sarakollé e os tucorores andavam à caça ao negro ao Sul do Senegal e a Oeste do Falémé, quer dizer na região do Futa Toro, e vendiam os cativos para Marrocos. O âmbar cinzento traziam-no os azalai que vinham das sebkas da costa (Trarza e Arguim). Os bosques de Acacia verek do litoral e da região entre Arauane e Tombuctu, assim como as pequenas matas de árvores da goma que se encontravam ao longo do mar até Arguim e na serra Bafor, davam a goma tão apreciada da indústria da sêda do reino granadino (452).

\section{3. - As pistas das cáfilas e as correntes de trocas - A têde central.}

Desde a primeira metade do século XI, senão muito antés, os negros exploravam as salinas de Tagaza, na extremidade ocidentalmeridional do erg Chech. Todos os anos os azalai - as caravanas do sal - chegavam, carregadas de barras, a Ghana e às outras cidades do império sarakollé. A cidade edificada em sal não era ain-

(452). - E1-Békri, p. 299. 
da, ao que parece, uma escala nas correntes de trocas entre o Maghrebe e o Sudão.

Na descrição de El-Békri e na Geografia de Edrici lemos por duas vêzes referências ao itinerário seguido pelas caravanas de Sidjilmessa a Ghana. Uma das vêzes, não há sombra de dúvida, percorrem o Sáara atlântico até Azogui, para rumarem depois ao Sueste. Os outros textos, ao invés, parecem descrever uma rota nova ligando quase em linha reta as duas cidades. Com efeito, segundo o geógrafo do século XI,

"Lorsqu'on part de Sidjilmassa pour se rendre à Ghana, dans le pays des noirs, on doit marcher pendant deux mois à travers un désert inhabité. Dans cette vaste région, on rencontre quelques nomades qui ne s'arrêtent nulle part"

e que não têm cidades (453). Reportemo-nos a Edrici: êle sublinha que nem de Dar'a a Azogui nem desta escala ao país de Uagadu se atravessa um deserto tão terrível como o de Nisar - 14 dias sem encontrar água; quantas vêzes a água transportada nas guerbas se esgota e é preciso matar camelos para beber as suas reservas de liquido. Como não ficar com a impressão de que se trata dos ergs ao Norte e ao Sul de Tagaza? Algumas frases de Ibne Saíde, reproduzidas por Abulfeda, dizem verossimilmente respeito a esta mesma pista: 50 jornadas de marcha de Sidjilmessa a Ghana percorrendo extensos desertos áridos... E' certamente tal rota que - planisfério do genovês Giovanni di Carignano (circa 1320) nos mostra: de Sidjilmessa a Ualata gastavam-se 40 dias através de desertos onde não se acha nenhuma povoação nem água.

Seja como fôr, é incontestàvelmente à exploração do sal em Tagaza que se deve o desenvolvimento, senão a própria gênese, desta pista mais curta desenhada através de um meio físico tão hostil. As escavações arqueológicas patenteiam que Tagaza vive sobretudo do que the vem do Norte. Os gêneros alimentícios, em especial as tâmaras, a utensilagem mineira de cobre, a baixela de louça vêm-lhe das regiões do Dar'a e do Tafilelte, e é do Norte que Tagaza é mais fàcilmente abastecida. Mas inversamente o produto único da sua atividade, o sal, só num sentido se escoa, e é o contrário: para o sul. Conseqüência lógica: a cidade de sal gema só pode existir como escala numa rota pela qual se permutam os produtos da Barbaria e os do mundo negro.

Se Tagaza atraiu a si, no decurso do século XIII, a via caravaneira que anteriormente conduzia do Tafilelte ao império sarakollé através do deserto de Nisar, não se julgue ser esta a única vicissitude dêste rio de trocas que tantos historiadores supõem imutável. Na verdade, a freqüentação desta pista, junta às ameaças 
dos "embuçados" de Audaghoste contra a capital negra, levaram à criação, cêrca de 1224 , de uma cidade nova a Nornordeste de Ghana e ao Sul de Tagaza, no Sahel: queremos nomear Ualata. A meio do século, o império sarakollé afunda-se sob a dupla pressão dos ataques dos cameleiros berberes e do crescimento da potência mandinga. Guerras e curvas de impérios que se limitam a traduzir a áspera luta pelo monopólio dos têrmos meridionais do tráfico trans-saariano; o fio condutor dêstes acontecimentos é o mesmo que Maurice Lombard surpreendeu na história das hegemonias no Maghrebe. Ao eclipse de Ghana corresponde a ascensão de Ualata, de oravante têrmo desta pista.

Foi êste o caminho que Ibne Batuta seguiu em 1352. Tendo descido ao longo do uede $\mathrm{Ziz}$, chegou, 23 dias depois de partir de Sidjilmessa, à cidade da mina do sal, onde passou 10 dias em sofrimentos e privações. Aqui é que a caravana fêz provisão de água para a travessia do deserto, que demora 10 dias; felizmente encontrou no caminho poças deixadas pelas chuvas, onde homens e animais mataram a sêde e se lavaram. Esta etapa conduziu-os a Taçarahla, outra aguada; aqui pararam três dias. Em seguida a cáfila atravessou o deserto de Djuf, e após uma semana de caminhada entrou no Sahel, percorrido pelos "bois selvagens" - os antilopes Addax; membros das tribos dos Messufah e dos Bardamah, vindos ao encôntro dos mercadores, vendiam-lhes odres cheios de água. Finalmente, ei-los em Ualata: tinham passado dois meses.

Em breve nova transformação, desta feita no têrmo setentrional, veio alterar a rota de Tagaza. Conflitos sociais em que a paupérrima plebe industrial e camponesa se opõe à opulenta classe dos comerciantes, estalam em Sidjilmessa. Como sempre, os nômades, êsses eternos salteadores das cidades cuja vida fácil e cujo luxo invejam, precipitaram-se sôbre um foco de riqueza convulsionado nos seus alicerces. Em 1362 os árabes D'ui'Amran, Monabbah e H'osain pilhavam e destruiam Sidjilmessa. O tráfico trans-saariano não desertou por completo o Tafilelte; é êle que nos séculos XV e XVI edificará ainda a fortuna das cidades novas de Tebuhasante e Manum. Todavia, estas recém-vindas nunca conhecerão o esplendor da antiga cidade, cuja derrocada aplanou o caminho ao florescimento de dois outros centros mercantis, um a Leste - Tuate - e o outro a Oeste - Ofram, no Anti-Atlas. A prosperidade de Ofram geraram-na as minas de cobre e de prata, a dos oásis tuatianos resulta do desenvolvimento de relações diretas com Tremecem que até aí comerciava com a Guiné ùnicamente por intermédio de Sidjilmessa.

Nesta época, novas transformações se tinham já operado no Sul. Junto ao Níger, a Nascente do lago Faguibine, no princípio do século XII, de uma aldeia de palhotas que nascera à volta do ano. 
1000 , cresceu uma cidade que será o maior empório sudanês durante a Idade Moderna. A partir da segunda metade do século XIV, Tombuctu vai açambarcar a parte de leão do comércio trans-saariano em detrimento de Ualata, assim como esta suplantara Ghana. De Tagaza as caravanas dirigem-se para Arauane, donde vão a Tombuctu. Todavia, a sua rival não se submerge, ao invés do que acontecera à capital sarakollé. E' que não só as cáfilas não cessam de aí chegar, mas também o início da exploração da sebkha de Igilde revigora a velha pista que ligava o Uagadu ao Adrar por Tichite. Ora, Ualata encontra-se precisamente na linha por onde têm de passar os azalai que se encaminham quer para Tombuctu quer para Mali.

Duas razões é possível aventar para explicar a exploração de novas salinas. Ter-se-ia dado uma baixa da produção em Tagaza ou em Trarza? Não é inverssímil. Esta baixa teria provocado uma alta đo preço do sal em Mali. Ora, Ibne Batuta conta-nos que na capital do império mandinga 4 barras de sal (a carga de um camelo) se vendiam por 20 a 40 miticais; segundo Cà da Mosto, um século volvido, a mesma quantidade valia, no mesmo mercado, 200 a 300 miticais; ao dealbar o século XVI, quando a sebkha de Igilde está já em exploração, a carga de sal e o camelo vendiam-se conjuntamente em Tombuctu, segundo Valentim Fernandes, por 100 a 120 miticais. Alta muito forte primeiro, baixa assaz sensível em seguida? Quão temerário seria afirmá-lo sôbre tais dados que não permitem qualquer construção científica. Mas a presunção persiste. Mesmo aceitando-os, uma outra hipótese fica em aberto: um ácréscimo da quantidade de ouro no mercado, seguida de uma contração. Poder-se-ia invocar igualmente um incremento da procura de metal amarelo, estimulando uma oferta maior de sal para o comprar.

Mercado do sal de Igilde, Uadam, a cidade a Leste do Adrar, venceu Azogui como nó das vias trans-saarianas ocidentais. Era evidentemente a antiga pista do Uagadu a Dar'a que fazia a sua fortuna, com a única diferença que freqüentemente as caravanas iam até Tombuctu em vez de ficar em Ualata. Em meados do século XV, Uadam era o grande fornecedor de ouro e escravos em proveniência do Sudão, a tôdas as cidades do Marrocos atlântico. O comércio com a feitoria portuguêsa de Arguim contribuirá também para o seu desenvolvimento. Uadam estava ainda em relações com Tagaza, e, por esta escala, com o Tafilelte e o Maghrebe central.

Estas cáfilas não se distinguem, quanto às mercadorias que circulam nos dois sentidos, das que estudámos atrás. Quando muito poder-se-á acrescentar, no rol das exportações do Sudão para - Norte, as nozes de cola (desde, pelo menos, o segundo quartel 
do século XIV) e o marfim; e na lista das importações em proveniência da Barbaria, os cavalos. E', contudo, bastante provável que estas mercadorias fôssem igualmente transportadas pelas caravanas do Sáara atlântico.

O fim do século XI e o comêço do século XII trazem-nos ainda a novidade de outra rota nesta rêde central, além da que liga diretamente Sidjilmessa a Ghana. Desta cidade sarakollé ia-se aos oásis de Uargla, no sul argelino; levava-se um mês a fazer a travessia do deserto, segundo Edrici: número evidentemente demasiado baixo. Não dispomos de informações àcêrca do itinerário; é natural pensar que passava pelo Tuate e Gurarah. Esta pista viveu longa vida, apenas o seu têrmo sudanês mudou: nos séculos XIV e XV Ualata e Tombuctu substituiram Ghana. Estas caravanas serviam Tremecem, Argel, Bugia e as cidades da Ifríquia. Parece que por vêzes, em vez de passarem pelos oásis tuatianos, faziam escala em Tabelberte, entre a bacia do Saura e - Tafilelte, donde se dirigiam para Tremecem.

\section{4. - As pistas das cáfilas e as correntes de trocas - $A$ rêde oriental.}

As ligações de que acabamos de falar são certamente recentes. E' preciso não esquecer, é verdade, que entre os oásis setentrionais o Tuate é que está a latitude mais baixa (pois o Tidikelte só em pequena parte se encontra povoado na Idade Média), e que é entre Tombuctu e Gao que o Níger mais avança para o Norte. Todavia, do cotovelo do rio aos oásis tuatianos a travessia é particularmente rude, porque se trata de um tanezruft, um deserto absoluto, completamente nu de vegetação e desprovido de água. Estas razões geográficas explicam que as caravanas tenham preferido durante muito tempo fazer um longo desvio, em vez de encurtar caminho.

Sublinhámos já que de tôdas as rotas trans-saarianas, as do Sáara central são incontestàvelmente as mais antigas. Ainda no século X, Ibne Háucal, que nada diz de pistas entre o Adrar mauritânio e o Adrar dos Iforas, descreve uma grande rota caravaneira cujo ponto de partida é na Tripolitânia, junto ao mar, Adjedabia; cortava o Fezzam, onde se dividia em dois ramos: um ia ter ao país haússa e ao Médio Níger (Dendi), com escala provàvelmente em qualquer povoação do Air, e outro desembocava em Gao, depois de passar pela serra dos Iforas. Dois séculos volvidos, Barca substituirá Adjedabia, em profunda decadência, e entre - pôrto marítimo e o Fezzam reanimar-se-á uma escala, Audjala, a Augila de Ptolomeu, oásis de tamareiras no meio das areias, muito freqüentado porque na rota que conduz quer ao Kaùar e ao Bornu, quer aos países a Leste do Níger. 
Paralelamente a esta pista de Barca ao Fezzam, uma outra se traçou desde cêdo mais a poente. Com ponto de partida em Tunes, descia a Nefzaúa, dirigindo-se seguidamente para Gadamés (oásis conhecido dos romanos sob o nome de Cydamus), continua. va para Ghate, donde ia ao Air e ao "país dos negros Kanem", ou seja à região entre o Médio Níger e o lago Tchade, imenso reservatório de magníficos escravos e foco de uma indústria têxtil cujos panos de algodão eram muito procurados. De Ghate um outro ramo ia a Gao, atravessando o Adrar dos Iforas onde Tadmekkete entra em concorrência com a cidade mais antiga de Sama, ambas, aliás, habitadas por berberes Mulethmin (embuçados) que tinham vindo sobrepor-se a uma população negra. Ao Norte, as caravanas vindas de Trípoli pelo Djebel Nefussa entroncavam também em Gadamés, onde carregavam peles da indústria local com destino ao Sul. Pela pista que do cotovelo do Níger ia a Barca e a Trípoli seguiam para o Mediterrâneo os "grãos do paraíso" - a malagueta, Afromomum Melegueta e Afromomum Granum paradisi especiaria cujas áreas de produção são o Alto Gâmbia e o Alto Níger, a Serra Leoa e sobretudo, evidentemente, a costa da Malagueta (454).

As caravanas que ligavam a Ifriquia ao Níger passando por Gadamés e Ghate sofriam a concorrência das que encurtavam caminho, conquanto à custa da travessia mais penosa do Adrar dos Iforas a Uargla, donde seguiam por Teggurte até as cidades da Barbaria oriental. Os oásis de Uargla e do Tafilelte eram os principais fornecedores de tâmaras ao Sudão. Do Maghrebe central e de Marrocos ia-se a Gao fazendo caminho pelo Tuate, Ahoggar e Tadmekkete, o mais tardar desde a primeira metade do século XIV. O Ahoggar tornou-se um nó de pistas caravaneiras por causa das suas pastagens, das suas glebas semeadas de cereais e dos seus palmares de tamareiras; é, porém, provável que no estabelecimento da rota Gao-Tadmekkete-Ahoggar, a mina de sal de Tuteke, na vizinhança desta última serra, desempenhasse papel de primeiro plano, tanto mais que estava em exploração desde pelo menos o século XI.

Para ir do Egito ao reino sonrhai podia-se ir primeiro a Trípoli ou Barca, e daqui quer a Gadamés quer ao Fezzam; a partir destas escalas sabemos já quais as pistas que levavam ao Níger. No entanto, as cáfilas não se davam geralmente ao trabalho de fazer êste desvio pelas cidades da Tripolitânia, internavam-se a direito de Siuah a Augila e daqui ao Fezzam.

Nesta teia caravaneira do Sáara central, uma rota segundo a direção do paralelo unia Gao aos oásis de Bilma, no Kaùar, por Takedda e pelo Sul do Air, tendo de atravessar dois tanezruft, um a

(454). - Conde đe Ficalho, Memória sôbre a malagueta. 
oeste e outro a levante desta montanha. Trata-se de uma das mais importantes correntes de trocas do mundo saariano-guineense, graças ao sal, indispensável à alimentação dos negros, e à pedra ume, de aplicação na tinturaria. As cáfilas partiam de Bilma carregadas de alumen e iam, quer pelo Fezzam, quer pelo Air, vendê-lo ao Egito, a Uargla e até a Marrocos. Os pães tronco-cônicos de sal, pelo contrário, seguiam o caminho do Air e de Takedda e eram vendidos nas cidades do cotovelo do Níger; expediam-nos igualmente para o Bornu.

Esta pista balizada por Bilma, Air, Takedda e Gao formava a metade oriental da grande rota que acompanha a orla do Sudão e do Sáara - a rota saheliana. Das cercanias da foz do Senegal vinha-se às cidades de Sanghana, Tacrur, Kugha e Audaghoste; daqui passava-se a Ghana, da cidade sarakollé continuava-se até Tiraca (a Leste do lago Faguibine), que Tombuctu destronará, e em seguida acompanhava-se o rio Níger até a capital sonrhai. Do mar ao Alto Senegal, ao Tagante, ao Uagadu, as cáfilas de dromedários e as pirogas acarretavam o sal, a goma, o âmbar. Em Audaghoste e Ghana, primeiro, em Ualata e Tombuctu desde o século XIII, vinham cruzar as cáfilas de metal amarelo vindas do Meio Dia; se uma parte do ouro tomava o caminho dos oásis sul marroquino e sul tremecenenses, outra corria pela rota desenrolada ao longo do paralelo, no sentido ocidente-oriente, enquanto no sentido oposto chegavam o cobre de Takedda (455) e os panos e outros tecidos do Egito.

\section{5. - Dos oásis setentrionais às cidades maghrebinas.}

Um dos fatos essenciais para compreender a circulação no Sáara e entre a Barbaria e o Sudão é o alinhamento, desde o Atlântico aos confins da Túnisia e da Tripolitânia, de uma série de oásìs a curta distância dos grandes centros maghrebinos. Ora os sedentários dêstes oásis sofrem de escassez de pão e carne, ao passo que dispõem de um excedente de tâmaras. Eis engendrado todo um movimento de trocas. Os nômadas comprarão as tâmaras contra gado; dos campos maghrebinos vão trazer trigo e cevada, para regressarem dos oásis com tâmaras que venderão nos suks da Barbaria, donde também trazem aos sedentários isolados, produtos industriais.

Um circuito comercial se fecha assim entre a fieira de oásis de tamareiras, ao Sul, e Marrocos, Tremecem, a Argélia e a Ifriquia, ao Norte. Entre os dois semi-círculos, os nômadas zenata e,

\footnotetext{
(455). - H. Lhote (Contribution à l'étude) pretende que êste "cobre" é afinal o sal de Teguidd n-Teçumt, conquanto reconleça a presença, nas imediaçóes, de ja. zidas cupríferas. Esta existência comprovada e a comprovada procura do metal pelos negros bastam para não seguirmos Lhote na sua correção ao texto trecentista.
} 
a partir do meio do século XI os beduínos, andam em constante vai-vem. Grandes cameleiros, sem dúvida, mas com rebanhos de gado miudo de longe mais ricos do que os dos "embuçados" Sanhadja; além disso, senhoreiam os campos de sementeiras no Tell, ao invés do que acontece com os cabildos que nomadizam entre a faixa dos oásis setentrionais e o Sahel sudanês. Além desta função de fornecedores de tâmaras e compradores de pão e produtos industriais, no circuito econômico que os liga ao Maghrebe, os oásis são indispensáveis escalas no tráfico trans-saariano. Alguns dentre êles têm ainda uma indústria, mineira e metalúrgica ou têxtil ou de couros; os seus produtos escoam-se para o mundo negro, donde em contra-partida recebem os escravos que formam a mão-de-obra de uma pobre agricultura.

No Sul de Marrocos as rotas trans-saarianas desembocam em três pontos principais: Nul, a que mais tarde Tagaoste fará vitoriosa concorrência, Ofram, perto das minas de cobre e de prata, na falda meridional do Anti-Atlas, e finalmente Sidjilmessa. De Nul, Tagaoste e Ofram as cáfilas carregadas de ouro, de escravos, de goma e de âmbar iam a Messa, onde se descarregava uma parte das mercadorias, pois os europeus vinham aqui por mar comprálas desde o século XIII; a caravana prosseguia até as cidades do Sus, centro da indústria do cobre e da indústria têxtil cujos produtos os negros solicitavam; do Sus enviava-se outra parte da carga, acompanhada do açúcar da produção local, para Aghmate e Marrocos. Nestas duas cidades do Haúz terminava igualmente um dos ramos do tráfico que ligava Sidjilmessa ao mundo marroquino: desciam-se as margens do uede $\mathrm{Ziz}$, para atravessar, em seguida, o deserto até Beni Sabih (no Dar'a), donde se subia o curso do Dar'a, e depois transpunha-se o Alto Atlas; a estrada em semi-círculo passando por Beni Sabih evitava o obstáculo do Djebel Sagho. Era êste o caminho que as caravanas percorriam nos séculos XI e XII. Ignoro quando se começou a frequientar uma outra via, mais curta, que da planície do Tafilelte subia o rio Rheris e o seu afluente Todg'ah, continuava para Leste pelo alto vale do uede Dadés (a pista desenhava-se entre o Alto Atlas e o Djebel Sagho) e galgava o Alto Atlas pelo vale de Teçaúte; a caravana fazia escala em Madinah (Damnat) e acompanhava em sequida o rio Tencifte até Marrocos ou dava meia volta à esquerda para ir a Aghmate. Ao todo, 8 dias ou pouco mais. O Tafilelte e o país de Dar'a comunicavam entre si quer pelo Norte do Djebel Sagho (vales do Todg'ah e do Dadés), quer, as mais das vêzes, ao longo do seu bordo meridional: nesta viagem mais curta, gastavam-se só 3 a 5 dias. Era por Dar'a que o Tafilelte e o Sus comunicavam; para ambas as regiões os sedentários de Dar'a exportavam o anil, que vinham comprar a Sidjilmessa os mercadores marroquinos e tremecenenses. 
O comércio de Sidjilmessa com Fez efetuou-se primeiro, ao que parece, por intermédio de Aghmate. Mas uma outra rota, direta, veio em breve concorrer com aquela. Orientada segundo o meridiano, passa por Sofroi, sobe o alto vale do Sebú até Mahdia, atravessa o Médio Atlas, desembocando em Cunaig-el-Gherben, depois cruza o alto vale do Meluia, galga a vertente setentrional do Alto Atlas para descer a falda meridional até Gerselvim, e acompanha finalmente o rio $\mathrm{Ziz}$. Eram precisos 9 dias a duas semanas. para se ir de Fez a Sidjilmessa. Rota das tâmaras, batizou-a Massignon.

A quarta pista que irradia do Tafilelte conduz a Tremecem. Vindo por Udid, atravessa o rio $\mathrm{Za}$ e corta todo o comprimento meridiano dos planaltos estépicos a nascente do uede Meluia e do Anti-Atlas, passando pelo sopé da extremidade oriental desta cadeia. 14 jornadas de marcha bastavam para ir de uma cidade à outra. Infelizmente, estas estepes estavam infestadas de nômadas que se compraziam em roubar os viajantes. Valia mais ir de Udid' a Taurirte e Guercif, meter pelo "corredor" de Taza até Fez, donde se continuava quer pela estrada de Aghmate quer pela estrada direta até Sidjilmessa. Este desvio apresentava a grande vantagem da segurança. Um dos traços mais curiosos desta rêde setentrional de trocas é que ainda durante a primeira metade do século XIV os mercadores de Tremecem negociavam com o Sudão por intermédio de agências estabelecidas na cidade do Tafilelte; a sociedade familiar dos al-Maqqarî constituiu um exemplo frisante. As caravanas entre Sidjilmessa e Tremecem calcurriavam aliás ainda uma outra via que pelo deserto e os oásis do uede Guir conduzia aos palmares do uede Zusfana, à cidade Figuigue, donde rumavam ao Norte pelos planaltos estépicos do Maghrebe central. Segundo Massignon, é a rota clássica do anil de Dar'a com destino ao reino de Tremecem. Em Figuigue entroncava na grande pista meridiana que ligava Tremecem e o Sudão quer pelos oásis dos uedes Zusfana e Saura e pelas escalas do Tuate, quer pelo ksar de Tabelbala. Desde o século XIII os peregrinos que vinham de $\mathrm{Fez}$ e iam para $\mathrm{Me}$ ca passavam igualmente por Figuigue; o seu itinerário, balizado primeiro por Sofroi e Mahdia, em coincidência, por conseguinte, com o itinerário que conduziria a Gerselvim e ao Tafilelte, transpunha em seguida o Médio Atlas no sentido do paralelo, atravessava o vale médio do rio Meluia, roçava pela ponta oriental do Anti-Atlas e seguia a direção noroeste-sueste pelos planaltos estépicos até o uede Zusfana. A rota de peregrinação tornou-se uma via comercial, no início do século XVI as caravanas transportam lanifícios, antimônio e chumbo.

Perto da extremidade meridional do uede Saura, os oásis tuatianos formavam a ponta de um outro leque de rotas em direção ao 
Maghrebe. Para o Noroeste, por Tabelbala ia-se a Sidjilmessa e daí a Aghmate ou a Marrocos. Para o Norte, as cáfilas iam a Tremecem passando por Figuigue. As pistas do Nordeste conduziam quer à Ifríquia, pelas escalas de Uargla e Teggurte, quer à $\mathrm{Ar}$ gélia pela escala do Mzabe. No Sul tunisiano o mesmo papel era desempenhado por Gadamés.

Esta fieira de oásis disposta segundo a direção do paralelo desenhava uma grande via do Oeste para Leste: Nul e Ofram, Dar'a Sidjilmessa, Tabelbala, Tuate, Gurarah, Uargla e Gadamés, até o Djebel Nefussa. Ao longo da costa mediterrânea havia uma outra grande rota, que por Tunes, Kairuam e Nefzaua descia também ao mesmo têrmo oriental. Entre as duas, uma terceira ia de Marrocos ao Djebel Nefussa por Figuigue, Mzabe e Teggurte. Do ponto de convergência das três, uma nova pista partia, que levava a Alexandria e ao Cairo acompanhando de perto o litoral.

\section{6. - As condições materiais das viagens e a vida das caravanas.}

Se considerarmos o conjunto das pistas do Noroeste africano, três traços fundamentais ressaltam. Por um lado, desenha-se no mapa uma espécie de quadriculado: as pistas trans-saarianas, dispostas segundo o meridiano, cruzam-se, ao Sul e ao Norte, com vias longas na direção do paralelo; deve notar-se a ausência de linhas horizontais entre a grande rota do Senegal,.Níger, Air e Kaùar e a grande rota definida pela fieira de oásis desde Nul a Gadamés. Em segundo lugar, algumas pistas em arco de círculo cortam êste quadriculado obliquamente, donde resulta a possibilidade de escolher entre vários itinerários, basta acompanhar uma determinada caravana só durante uma parte do seu percurso, até uma escala que forme foco de irradiação de pistas, e aqui mudar para outra caravana que siga uma direção diferente. Numa palavra: trata-se de uma rêde de agulha múltipla. $\mathbf{E}$ esta rêde, que historiadores $\mathrm{e}$ geógrafos se comprazem em apresentar como imutável no decurso dos séculos, vimos que ora se completa com novas linhas, apagandose uma ou outra das antigas, ora alguma das suas linhas se torce enquanto outra se desloca, e os têrmos surgem e desaparecem: tratase incontestàvelmente de uma rêde em devir, embora no meio das transformações se apreendam algumas constantes.

Que é que define estas rotas? Uma rota é determinada pelas suas escalas principais, os polos definem tão só uma corrente de trocas. Ora, tais escalas são função dos meios de locomoção - das suas velocidades, das suas capacidades de transporte e das suas necessidades de renovação de energia. Ao imenso círculo cultural das estepes euro-asiáticas, onde o nomadismo se baseia na utilização do cavalo, podem opor-se os desertos saariano e sírio-árabe onde o camelo constitui a montada e o animal de carga. Decerto, no 
Sáara utilizam-se outros meios de locomoção: é o caso dos bois e dos burros de carga no Sáara atlântico e sub-atlântico; rebanhos de cabras e carneiros vão do Adrar dos Iforas ao Tuate, e manadas de bois passam do Ahoggar ao Air. No entanto, nestes dois últimos casos de modo algum poderia pensar-se em carregar as bêstas ou em cavalgá-las, a travessia é extremamente penosa e precária, só o lucro na venda da carne explica que os nômades a efetuem com regularidade; no primeiro caso, bois e asnos não caminham longos percursos - não são as galés dêste Mediterrâneo de areia e pedra. Como a travessia do deserto é também penosíssima para o cavalo, só nas imediações dos oásis no Sahel e no Sáara pré-maghrebino é possível encontrar cavaleiros, em número reduzido.

Uma cáfila de camelos marcha à velocidade horária de $3,5 \mathrm{~km}$. a $4 \mathrm{~km}$., em média; como a jornada de marcha é normalmente de 10 horas, percorrem-se por dia 35 a $40 \mathrm{~km}$. (456). Para ultrapassar os 5 $\mathrm{km}$. à hora tem que se trotar, conseguem-se assim velocidades horárias de 8 a $20 \mathrm{~km}$, consoante o ritmo do trote. Percorrer mais de $60 \mathrm{~km}$. num dia é excepcional. E' extremamente raro levar a velocidade e o número de horas de marcha ao ponto de fazer numa jornada $120 \mathrm{kms}$; para além dêste limite, há a certeza de matar a montada (457). Tais cavalgadas, evidentemente, só são possíveis a alguns batedores que dromedários carregados de fardos não embaraçam. Quando se caminha com bêstas de carga, jamais se ultrapassam os $4,5 \mathrm{~km}$., à hora; é preciso ter em conta não só os: animais mas também os homens porque os há sempre que acompanham a caravana a pé - criados ou escravos.

E' de madrugada que se começam a carregar os camelos e os bois, se os há; trata-se de operação delicada e que se prolonga durante duas ou três horas, porque as bêstas resistem, procuram deitar ao chão os fardos - e com freqüência o conseguem -, gritam de maneira espantosa, e por vêzes um animal que se desembaraçou da sua carga foge

"atropelando os outros animais, bois ou camelos, que, excitados, se libertam por seu turno das cargas" (458).

À medida que os dias passam e a fadiga aumenta, torna-se mais fácil e portanto mais rápido carregar as bêstas e pôr a cáfila em marcha. A caravana anda de madrugada e durante as primeiras horas da manhã, até que o sol

"communique à l'air et à la terre une chaleur insupportable. Alors on s'arrête, on décharge les chameaux et on les entrave; on déballe les marchandises et on dres-

\footnotetext{
(456). - Segundo Joäo de Barros (Década I, liv. 9, cap. 1), no percurso Cairo-Suez em três jornadas de camelo anda-se no mais 24 léguas. Assim o máximo da jornada corresponde a $48 \mathrm{~km}$.

(457) . - Gruvel e Chudeau; Monod.

(458). - Gruvel e Chudeau.
} 
se les tentes en tâchant de se procurer de l'ombre à fin d'éviter l'influence fâcheuse de la chaleur des rayons solaires. Lorsque le soleil commence à baisser, à trois heures et demie après midi, on repart et on marche jusqu'après la nuit close. On s'arrête de nouveau quelque part qu'on s'en trouve, et on se repose le reste de la nuit, jusqu'au crépuscule du matin, quand on reprend le voyage" (Edrici).

mente - o limite é de 10 dias, em certos casos 16 - e a travessia do deserto do Norte ao Sul, ou vice-versa, qualquer que seja a pista escolhida, leva cêrca de dois meses. E' indispensável, de tempos a tempos, matar a sêde aos animais, e se o camelo aguenta vários dias a sêco, vinga-se quando encontra água e bebe desalmadamente, pois a sua necessidade diária é de 60 a 70 litros; além disso, tem também as suas necessidades alimentares, mais urgentes: 20 a $30 \mathrm{kgs}$. por dia de uma alimentação vegetal onde não deve faltar o sal e que deve ser variada ao menos ao longo das estações do ano; de cada vez são 4 a 5 horas que o animal leva a comer (459). Por isso a caravana terá de seguir uma rota que passe pelo maior número possível de poços e de pastagens. O homem, êsse, pode fazer-se acompanhar de dromedários suplementares para se sustentar da sua carne ou para que lhe transportem odres de água; não pode, porém, esquecer-se de que assim o problema da água para os animais se torna mais difícil de resolver. Pela melhor das pistas só de dois em dois, ou de três em três dias se encontra água, apenas excepcionalmente, durante curtos trechos do caminho, é possível dar de beber aos animais cotidianamente. Uma semana inteira sem avistar a mais pequenina gôta, é tão freqüente, e por alguns itinerários anda-se durante duas semanas nestas condições.

Antes de partir, a caravana tem de fazer provisão de água, e tem de renová-la muitas vêzes. Para êste efeito, compram-se odres de couro, que se embrulham em tapetes ou untam exteriormente com uma resina, a fim de diminuir a evaporação e evitar o aquecimento do líquido. $\mathrm{Na}$ Mauritânia saariana, por exemplo, êstes odres, a que chamam guerbas, são feitos de peles inteiras de cabras ou de carneiros; cada uma leva uns 201 . Cosem-se

"toutes les ouvertures, sauf une, celle du cou, par laquelle on remplit et on vide cette sorte d'outre. Quand la guerba est pleine, on serre fortement la peau du cou avec une corde et on fixe l'outre de chaque côté d'un animal porteur, à l'aide de cordes qui sont attachées d'une, palte à l'autre, non symétriques".

Se a água apanha assim um cheiro desagradável, conserva em compensação uma certa frescura (460). A aguada faz-se por vê-

(459). - Capot-Rey, Géographie de la circulation, pp. 61-64.

(460): - Gruvel e Chudeau. 
zes em poças ou charcos deixados pelas chuvas, mas geralmente pressupōe todo um sistema de poços prèviamente construídos e que se. está de antemão certo de poder referenciar. Apesar de tôdas estas. precauções, acontece freqüentemente que a água acaba por faltar; como recurso supremo, há que matar um ou mais camelos para beber as suas reservas de líquido.

A abertura e conservação dos poços é feita quer pelos nômadas quer pelas autoridades sedentárias. Mas as tribos do deserto é que, em geral, têm nas mãos o destino das caravanas, porque podem tapar os poços ou impedir o acesso. Por outro lado, os mercadores é junto delas que contratam os guias para a travessia do deserto. Esta travessia só é possível a caravanas regulares graças à experiência acumulada das tribos; estas é que levaram a cabo a exploração do deserto, referenciaram os itinerários mais cômodos e os poços indispensáveis. Por isso, o guia é sempre um nômada, um "embuçado", o que tem ainda a vantagem de garantir à cáfila a proteção da tribo a que êle pertence (Ibne Khaldun). Numa carta portuguêsa de 1511, que descreve o tráfico entre o Egito e o Sudão ocidental, lê-se uma bela fórmula: as caravanas

$$
\text { "têm pilotos para os guiar neste caminho"; }
$$

êstes pilotos orientam-se pelas estrêlas. Três séculos e meio atrás, Abû Hâmid al-Andalûsi al-Gharnâti escrevera em têrmos análogos que os mercadores cujo caminho é pelos areiais que parecem mares,

"ont avec eux des guides qui s'orientent dans les déserts d'après les étoiles et les montagnes" (461).

Algumas vêzes o guia é quase cego, acompanha-o então um ajudante que vai procurando com a vista os acidentes naturais que o outro lhe descreve de memória. As caravanas de Sidjilmessa a Ualata faziam-se preceder, a partir de Taçarahla, de um mensageiro que levava as cartas a avisar da chegada dos comerciantes, a fim de que os habitantes da cidade viessem ao seu encôntro à distância de 4 jornadas, com água.

Apesar de tudo, como era frágil a vida das caravanas! Se o mensageiro enviado de Taçarahla se perdia ou morria, os mercadores sucumbiam todos ou pelo menos a maior parte, de sêde (Ibne Batuta). A água faltava as mais das vêzes, salvo num ou dois itinerários particularmente favorecidos. Em geral, a água que a tanto custo se conseguia encontrar era salobra. $\AA$ angústia da sêde acrescentava-se por vêzes a da fome, mas com muito menor frequiência visto que a montada ou a bêsta de carga constitui ela própria uma reserva de alimento; mas pode faltar a lenha para cozinhar, é cor-

(461). - Journal Asiatique, 1925, pp. 243-245. 
rente comer a carne simplesmente sêca ao sol. Ainda há que suportar tanto o calor excessivo do dia, devido ao qual se chega a urinar sangue, como o frio da noite, os enormes saltos de temperatura. E não é raro que uma violenta tempestade de areia venha perturbar a marcha da caravana, matando até homens e animais, cegandoos, secando-lhes a garganta a ponto de tornar extremamente dolorosa a sensação de sêde.

$\mathrm{E}$ ainda se os perigos do meio físico fôssem os únicos a correr! Mas há também ter em conta os nômadas que espreitam a ocasião da pilhagem...

\section{7. - A orgnaização das caravanas. Mercadores e emprêsas.}

Na verdade, a vida do "mar arenoso e pedregoso", não é só nas suas "ilhas" - os oásis - que se concentra, nem bate apenas, fora delas, nas suas artérias de navegação regular - as caravanas. Os cabildos azenegues e alarves, agregados de famílias cada qual em sua tenda, contando ao todo 300 a 500 homens de pelêja, vivem navegando constantemente de poço em poço, de pastagem em pastagem, sem jamais pararem mais de três dias no mesmo local. Conquanto a sua economia assente na criação de gado, também exercem o comércio e dispóem dos excedentes entregues pelos sedentários dos oásis que tiveram de se submeter ao seu senhorio. Não são, contudo, as deslocações dos cabildos nômades que asseguram a grande circulação mercantil, esta constituem-na geralmente caravanas organizadas por mercadores maghrebinos ou negros. Decerto, seria errado esquematizar em excesso as relações entre as duas "navegações". Se um cabildo aproveita as suas deambulações para veïcular uma corrente de trocas, alguns dos seus membros acabam, cêdo ou tarde, por se instalar na cidade, ou criar mesmo uma cidade, a fim de se consagrar ao negócio de maneira mais vantajosa. Outras vêzes, o grupo nômada que viaja forma ao mesmo tempo uma caravana:

"Quand ils (os Dui Obeid Allah e os Beni Amer) quittent le Tell avec leurs troupeaux pour se rendre dans cette région (Gurarah), les caravanes formées par les ville du Tell se joignent à eux et les accompagnent à Tamentit".

Não raro um mercador sòzinho ou uma pequena companhia agrega-se a um cabildo em viagem, para atravessar de um oásis para outro.

Além disso, são as tribos nômadas que fornecem aos comerciantes as montadas e as bêstas de carga. E' evidente que sairia excessivamente caro aos citadinos criar camelos de que não aproveitariam o leite nem a carne; e de resto essa criação é incompativel 
com a permanência duradoura num local. Os mercadores, quando querem formar uma caravana, compram os animais aos nômadas que freqüentam os arredores; depois de chegarem a Ualata ou a Tombuctu, vendem-nos, poupando assim as despesas do sustento durante as semanas que se demoram nos mercados sudaneses. Chega o dia do regresso: de novo se dirigem aos nômadas para lhes comprar dromedários, de que revenderão os sobreviventes à chegada às cidades da Barbaria.

Durante a viagem, as caravanas são guiadas por "pilotos" que pertencem às tribos nômadas. Essses guias garantem ao mesmo tempo a segurança em relação à tribo de que são membros, e até eventual proteção dessa tribo contra tentativas de outras.

E' que os nômadas cameleiros, embora se jactem de grandes senhores, arrastam uma existência miserável no deserto, cobiçam as riquezas das cidades e das cáfilas de comércio. As suas tribos ou os seus cabildos estão quase constantemente travados de razões: feroz concorrência pelas aguadas e pastagens, pelo senhorio dos oásis, vinganças de sangue, rezzus e contra-rezzus de pilhagem para tapar deficiências ou cevar cobiças.

Estas condições sociais, vindo juntar-se às condições materiais da viagem, forçam os comerciantes a reunir-se em caravanas e a organizá-las sob uma disciplina éstrita. À frente uma bandeira abre - caminho; a partida é anunciada pelo rufar do tambor. Cada caravana obedece a um chefe. Os seus membros não devem afastarse da cáfila, porque é fácil perder-se: e quem se perde tem a certeza da morte. Entre si, têm deveres de solidariedade, que não podem deixar de cumprir sem incorrer na reprovação unânime. Se um camelo cai morto, o mercador sem montada monta o camelo de um dos companheiros; se os odres de um dêles, seja qual fôr, já não têm água, os outros oferecem-lhe de beber. Os mercadores fazem-se acompanhar por uma escolta, que muitas vêzes lhes é cedida por uma tribo nômada cuja proteção pediram, ou é constituída pelos escravos e servidores; aliás tôda a gente usa armas. Se os salteadores thes saem ao caminho, a caravana pode defender-se, mas em geral prefere pagar resgate razoável, se fôr possivel, e na maior parte das vêzes comprou, antes da partida, salvos-condutos aos chefes das diferentes tribos. O nômada que concedeu a sua proteção empenha a sua honra, ficaria por isso completamente desacreditado junto dos outros nômadas se faltasse à palavra dada. Algumas tribos eram especialmente perigosas; tais os Ahoggar, a quem Ibne Batuta chama verdadeiros ladrões, que não deixavam passar as cáfilas sem as pilhar a não ser durante o mês de Ramadam; tais, também, os Lamta, cujo covil era a serra Bafor.

Os reinos maghrebinos e sudaneses tinham evidente interêsse em garantir a segurança das caravanas; muitas das ações da sua 
história explicam-se mesmo pela necessidade de deitar mão às principais rotas a fim de assegurar a livre circulação. Em Sidjilmessa organizavam-se freqüentemente expedições militares cujo objetivo consistia em punir os nômadas: al-Qastallânî contou que quando esteve no Tafilelte viu no palácio do governador montes de crânios dos bandidos que tinham o mau costume de assaltar as cáfilas que iam para Ghana (informação de entre 1197 e 1203) (462). O império almorávida que é senão um império das estradas do ouro? Os Almóadas e, mais tarde, em Tremecem, os Abde el-Uaditas esforçavam-se por policiar as pistas trans-saariana. Era o mesmo alvo que visavam os impérios mandinga e sonrhai com o domínio de Tagaza e de tôdas as escalas meridionais do Senegal ao Air. Quando a desordem perturbou o Maghrebe, foram as sociedades comerciais que retomaram à sua conta esta política: por exemplo, a dos al-Maqqari.

Apesar de tudo, o melhor ainda era pagar peagem às tribos nômadas. Desde que, a partir de meados do século XIV, os árabes se espalharam para o Sul da Seghiet el-Hamra, as suas tribos conseguiam reduzir à vassalagem as tribos de "embuçados", que passaram a pagar-lhes páreas e além disso, para exercerem o comércio do Sudão, o dízimo das mercadorias transportadas; os negros recusaram-se a entabolar relações com os beduínos, que reputavam ladrões, e não lhes consentiam que fôssem traficar às suas terras.

Os mercadores do tráfico trans-saariano são de dupla origem. Por um lado, trata-se de citadinos quer da Barbaria quer do mundo negro. Por outro lado, trata-se de nômades que se instalaram na cidade, ou até de nômades que não deixam de o ser. Encontrâmo-los por tôda a parte: em Aghmate, nas cidades do Sus, em Messa e em Nul, em Ofram e Sidjilmessa, em Marrocos e Safim, em $\mathrm{Fez}$ e Ceuta, em Tremecem, em Figuigue, no Tuate, em Bugia, em Gadamés, nos mercados do Sahel e do Senegal-Níger. Até o século XII, ao que parece, só os muçulmanos do Maghrebe e os "embuçados" se dedicam a êste negócio; desde o ocaso do século XII, os sudaneses fazem a viagem do Sáara para ir traficar no Marrocos sul-ocidental (463). De cada caravana fazem parte mercadores das proveniências mais dispares. Os marroquinos e tremecenenses são particularmente numerosos nas cáfilas do Tafilelte. No Tuate, em meados do século $X V$, cruzava-se nas ruas com não pequeno número de judeus; o poder do seu dinheiro e a sua influência social atrairão sôbre as suas cabeças, ao findar a éra quatrocentista, as iras da plebe. Um comerciante do Djebel Ne-

(462) - - Apud Pérès, Mélanges Gautier, pp. 411-412.

(463). - H. Pérès, nas Mélanges Gautier, p. 410 . 
fussa, Abu Rostem, freqüentava regularmente, no século XI, o mercado de Audaghoste (464).

Os pobres ksurianos Beni Gumi, do uede Guir, vão para Fez trabalhar em ofícios "mecânicos e vis"; com o magro pecúlio dolorosamente poupado sôbre o fruto do seu labor, compra cada um dêles um cavalo, que entrega aos mercadores para êstes tho venderem aos negros, trazendo de retôrno ao artífice uns gramas de ouro. Todavia, regra geral, os pobres não participam no grande tráfico trans-saariano. Um fôsso profundo separa ricos e pobres nos oásis setentrionais e nas cidades maghrebinas e sahelianas, o poder político está nas mãos de uma plutocracia.

Estamos em frente de negociantes de grossos cabedais, agindo individualmente, ou de sociedades familiares, ou de comanditas ou de sociedades em nome coletivo? Dispomos de muito poucas informações para emitir um juízo; o mais provável, porém, é que tôdas estas formas funcionassem. Conhecemos uma poderosíssima sociedade familiar, a dos cinco irmãos al-Maqqarî, naturais de Tremecem. Tendo feito um monte comum de todos os seus bens, partilhavam os lucros em quinhões iguais. Dois dêles ficaram na cidade natal, outros dois estabeleceram-se em Ualata, onde casaram e tiveram filhos. Um quinto instalou-se em Sidjilmessa, donde informava uns e outros das cotações das mercadories - altas e baixas - nos três mercados: era como que o fiel da balança, regulando a oferta e a procura. Assim amontoaram uma fortuna considerável e sólida, e vieram a ser os "amigos muito íntimos" e os "companheiros muito queridos" dos reis e imperadores, com quem trocavam correspondência. Esta ascensão desenrolou-se verossìmilmente durante o primeiro quartel do século XIV; os netos, como é norma, começaram a espatifar a fortuna, mas esta resistiu ainda por muito tempo às loucuras (465). Malfante, alojado em 1447 no Tuate, foi recebido como "cliente" por um dos cabeças de bairro; o seu protetor era irmão do maior negociante de Tombuctu. Em Ualata Ibne Batuta alugou uma casa cujo proprietário era uma personagem distinta de Salé que viera viver para a cidade do Sahel; decerto deixara sócios na cidade natal. Em Mali o mesmo viajante encontrou um letrado de origem marroquina, um egípcio e um xeque natural de Tremecem.

Vemos, por conseguinte, que se a maior parte talvez dos mercadores acompanham as suas mercadorias e efetuam êles próprios as operações comerciais nos diferentes mercados, há grandes emprêsas com uma rêde de feitorias, administradas por comerciantes que não se deslocam. Eram os empregados ou os escravos destas sociedades que iam nas caravanas para acompanhar as bagagens;

(464). - Ej-Békri.

(465): - Al-Maqqari, Nalh at-tib, apud Pérès, Mélanges Gautier, pp. 412-414. 
chegados ao destino, entregavam os fardos a um mercador estabelecido na praça e sócio da mesma casa comercial (Edrici declara-o explìcitamente ao falar dos opulentíssimos burgueses de Aghmate).

Seria muito importante avaliar os cabedais, o movimento de caixa e o pêso dos carregamentos. Infelizmente nada sabemos, por absoluta falta de dados quer quanto a estas variáveis, quer quanto aos preços. Sabemos, pela experiência moderna, que um camelo transporta uma carga de 120 a $150 \mathrm{~kg}$. em média; um pêso de 200 $\mathrm{kg}$. basta muitas vêzes para o derrubar de fadiga. As cáfilas MaliTakedda-Cairo compunham-se em geral de 12.000 dromedários (Ibne Khaldun). O azalai das minas de sal do Kaùar a Agadez contava, no princípio do século XX, não menos de 20.000 camelos, e na Idade Média o número não era sem dúvida inferior. Dêstes números há que subtrair as montadas e as bêstas que transportam os odres de água e os abastecimentos. Não era com certeza menos de 1 milhão de quilos de sal que anualmente chegava de Bilma ao Air e ao Níger. Mais interessante ainda seria conhecer o pêso de ouro exportado para o Egito e para o Maghrebe pelo Sudão ocidental. No nosso tempo, a mineração indígena produz por ano mais de 4.000 quilos; a produção era seguramente superior na Idade Média, período de esplendor da mineração, uma vez que a técnica não se aperfeiçoou; vale a pena sublinhar que 40 a 50 camelos bastariam para transportar tôda a produção atual. Ora as caravanas que levavam o ouro de Tombuctu para Tunes no século XV contavam cêrca de 700 camelos (Diogo Gomes-MartimBehaim). No século XII, cada mercador de Aghmate possuia, em cada cáfila que fazia a viagem da Guiné, 70 a 100 bêstas de carga.

Ibne Háucal viu em Audaghoste
"un papier sur lequel un natif de Sidjilmassa se re- connaissait le débiteur d'une personne de la même ville pour une somme de 40.000 dinars, chose dont je n'ai ja- mais trouvé un semblable example".

Esta dívida representava um pêso de ouro de 150 a 180 quilos. A essa data a taxa cobrada sôbre as caravanas do Sudão, os impostos, as rendas da alfândega e o contrato da casa da moeda rendiam ao todo, em Sidjilmessa, 400.000 dinares. Em 1447, a fortuna de um dos mais poderosos negociantes do Tuate elevava-se a mais de 100.000 dinares.

\section{8. - As caravanas do ouro e a evolução monetária do Egito medieval.}

A evolução monetária do Egito divide-se em quatro períodos. Até o fim do século XII, é o reinado da moeda de ouro, durante os séculos XIII e XIV, o reinado da moeda de prata, destronado no 


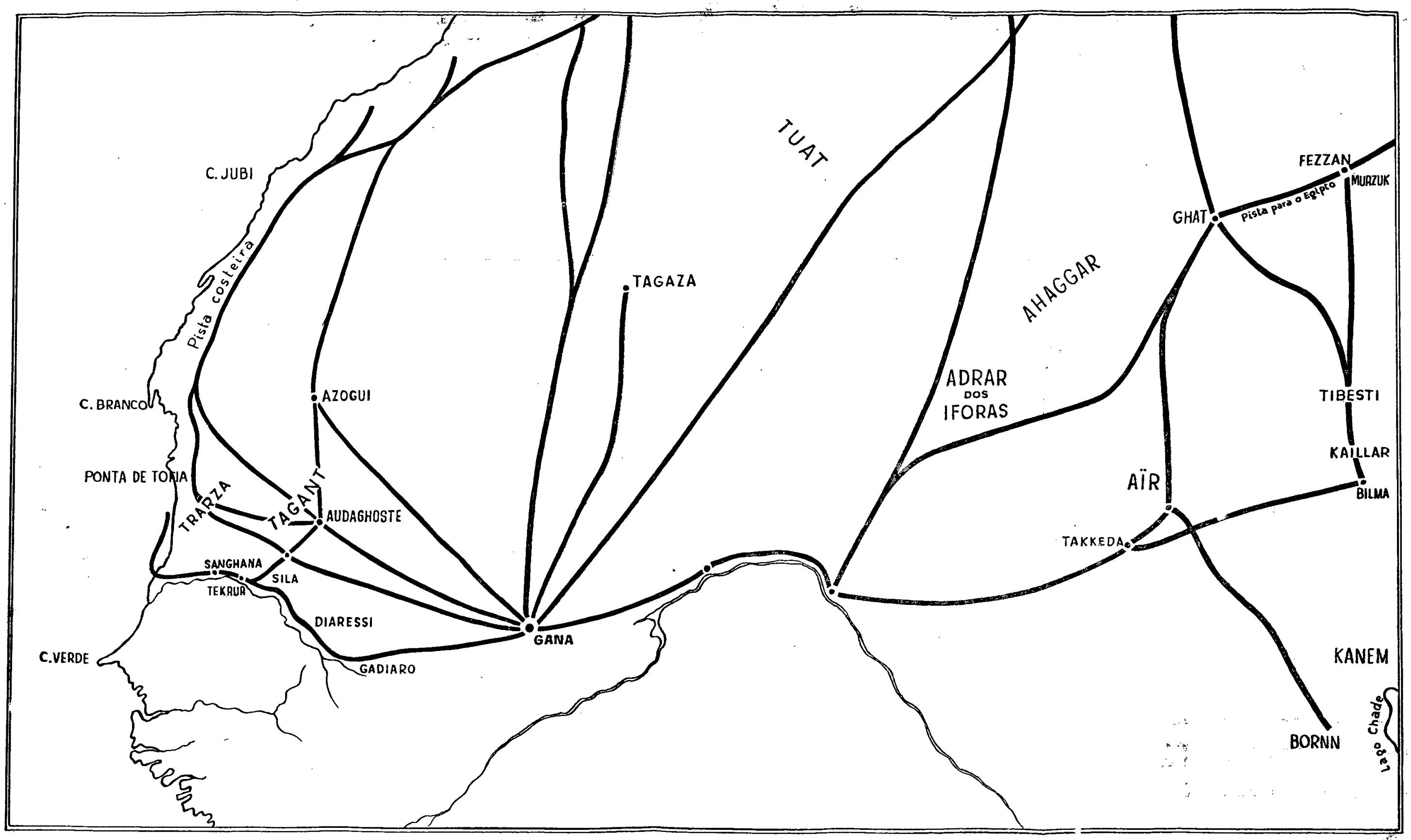

aS PISTAS TRAnS - SAaRianas nOS SÉculos XI-XII 


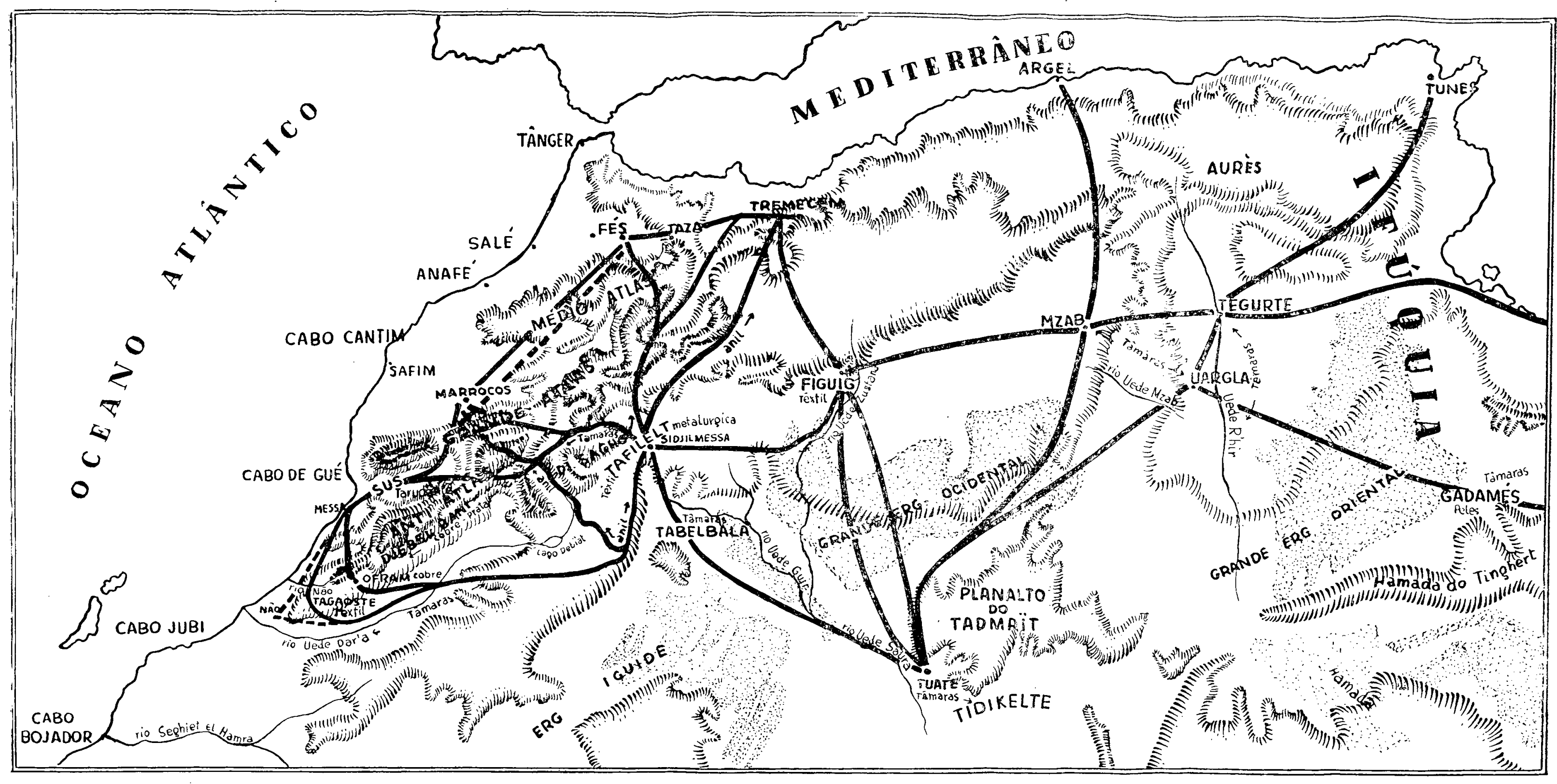

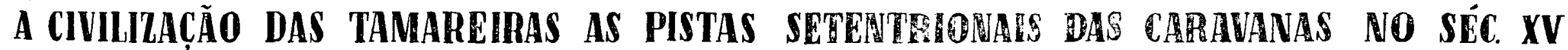




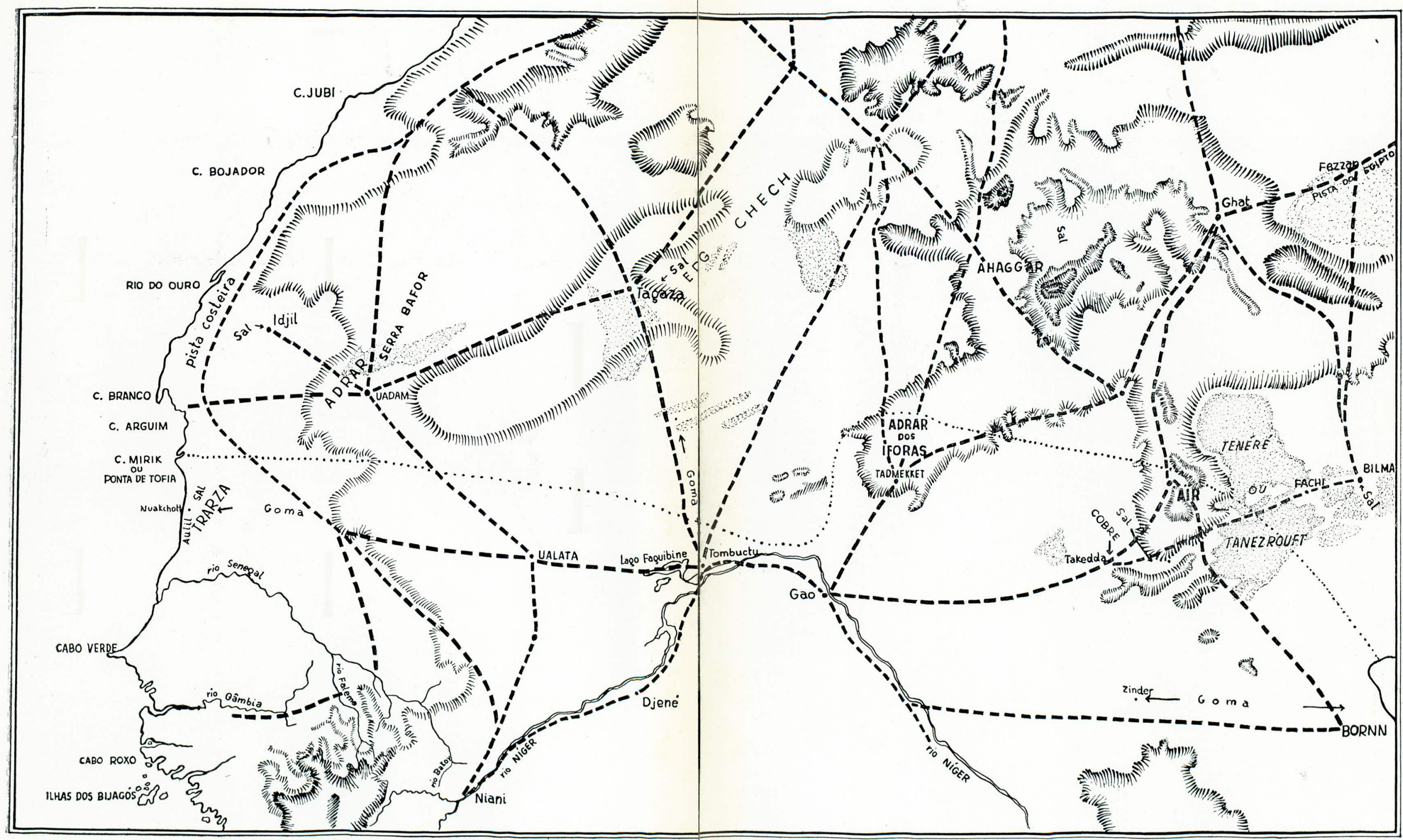

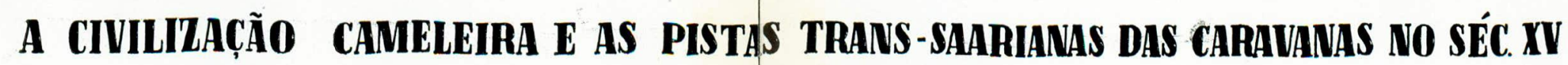


século XV pela moeda de cobre (466); em 1518, regresso à grande circulação do metal amarelo. A hegemonia do numerário de ouro até o fim do século XII deve-se ao lançamento do metal entesourado na circulação, à chegada de metal em proveniência do Alto Nilo, e às espécies ifriquianas cunhadas com o ouro sudanês, que afluem ao mercado egípcio, bem como à importação direta dêste metal pelo veículo das cáfilas vindas do Níger. O grande fato da passagem, no Egito, do reinado da moeda de ouro ao da moeda de prata, explica-o Maurice Lombard não só pelas razões já alegadas por De Bouard, mas também, e principalmente, pela invasão hilaliana na Ifríquia, a qual teria cortado as rotas que pelo Sáara Oriental, o Djérid e Trípoli abasteciam o reino fatímida. Explicação elegante, entra num quadro clássico de explicações em história; com efeito, recorre-se geralmente a êstes cortes de comunicações para explicar não pequeno número de correntes ou conjuntos de acontecimentos. Todavia, cabe perguntar se existem verdadeiramente provas dêste corte, por outras palavras, se as fontes atestam que os beduínos impediram realmente as caravanas de circular entre o $\mathrm{S} u$ dão e o Egito.

Os Beni Hilal e os Beni Soleim estabeleceram de início os seus terrenos de percurso na Tripolitânia ocidental e ao Sul da Tunísia; lançaram a desordem na Ifríquia, saquearam as cidades, ermaram e devastaram os campos: estamos de acôrdo. Os numismatas constatam a rarefação das moedas de ouro sob os $Z$ iridas, a partir do meados do século XI (467). Apesar de tudo, o ouro e os escravos continuam a chegar aos pontos mediterrâneos - o próprio Lombard nota que $o$ comércio genovês se desenvolve; como os beduínos ocupam os territórios sul-tunisianos, deveriam ter também interrompido por completo a chegada de mercadorias sudanesas a Kairuam e Tunes, ora isso não se dá. Fato estranho. Na posse desta encruzilhada de pistas, teriam fechado só uma delas, deixando a outra entreaberta? Se assim é, eis um problema novo, que é indispensável pôr e tentar resolver.

Alguns testemunhos parecem, todavia, infirmar a hipótese de Lombard. A Geografia de Edrici, que não se esquece de anotar os prejuízos causados pelos árabes, nada diz desta interrupção de rotas quer para a Ifríquia quer para o Egito. Pelo contrário, fala com tôda a clareza do tráfico dos oásis e das cidades do Sul da Tunísia e da Tripolitânia com a Terra dos negros, descreve as pistas que dessas regiões conduzem ao Egito. Estamos a meio do século XII, ou seja um século depois de os Hilal e os Soleim invadirem esta encruzilhada. Não será, aliás, de estranhar que a grande circula-

\footnotetext{
(466), - A fonte principal para esta divisão en períodos é o Tratado das moedas

(467). - H. W. Hazard, The Numismatic History of Late Medieval North Africa New York, 1952 .
} 
ção Gảa moeda de ouro no Egito desapareça só no fim do século XII e comêço do século XIII, cento e cinqüenta anos volvidos sôbre o acontecimento-causa? Decerto, havia os stocks ainda a esgotar: mas bastariam para assim protelar o efeito?

No século XIV, dois testemunhos muito precisos mostram-nos a Guiné em relação perfeitamente regulares com o país nilótico. Aí está a narrativa de Ibne Batuta. Não nos informa de que no império de Mali é corrente o uso de panos e lanifícios vindos do Egito? Quando fala de Takedda, sublinha que os habitantes da cidade mineira fazem todos os anos uma viagem ao Egito, donde trazem para o seu país belos tecidos e outros artigos. Durante a viagem de regresso ao Maghrebe, Ibne Batuta chega ao ponto onde se separam o caminho de Ghate e o do Tuate; não se esquece de nos di. zer que o primeiro vai ter ao Egito. Mais decisivo ainda é o texto de Ibne Khaldun: todos os anos uma cáfila de 12.000 camelos vai do Cairo a Mali, passando por Takedda.

No século XV continuava a ser assim, se dermos crédito às informações de Cà da Mosto: as caravanas ligavam Mali ao Cairo, fazendo escala em Kukya. A carta de Malfante, de 1447, revela-nos que havia relações mercantis regulares entre Alexandria e - Sudão ocidental por intermédio do Tuate.

Estes fatos parecem contradizer a idéia de uma ruptura dos laços entre o Egito e os países negros do Níger em conseqüência da invasão hilaliana. Todos conhecem a tese clássica de Marçais: os beduínos, sob a impulsão de uma insensata política fatímida, irromperam, em meados do século XI, pela Ifríquia dentro, e, conseqüência inesperada para os que os lançaram nesse caminho, cortaram as pontes entre a Barbaria e o Oriente, tanto do ponto de vista político como do ponto de vista cultural. Donde se conclui, naturalìssimamente, que o ouro sudanês, amoedado na Ifríquia, deixa de seguir para o Egito. E' necessário, porém, acrescentar imediatamente: as caravanas continuam a ligar diretamente o país do Nilo e o mundo negro, há até que vincar que a rota principal fica fora do alcance dos Beni Hilal e dos Beni Soleim, visto que do cotovelo do Níger vai a Ghate e daqui ao Fezzam, para passar em seguida por Augila e Siuah. Assim, em vez de receber o ouro pelo desvio das cidades ifriquianas, os egípcios podem recebê-lo diretamente dos reinos negros.

Se não o recebem, não será talvez porque dêle não precisam? Tal conclusão, assaz lógica dadas as premissas, desloca o problema. Com efeito há agora que responder à pergunta: por que é que deixaram de precisar dêle? Noto, antes de mais, que o desaparecimentos da grande circulação das moedas de ouro no Egito desenrola-se em processus bastante lento; só no princípio do século XIII terá terminado. Sucede-lhe o estalão prata, e no século XV·o co- 
bre. Voltemo-nos para outro lado. Não se dá, precisamente do século XI ao século XIII, um progresso considerável do comércio das especiarias pelo Mar Roxo? Constata-se então a ascensão do mercado egípcio e do mercado sírio. Ora as especiarias, compramse nos portos do Malabar por prata, e nas ilhas malaias por cobre, e não, em geral, por ouro. Uma hipótese pode, por conseguinte, es clarecer a evolução monetária do Egito: se o reino mameluco pảssa ao estalão prata e depois ao estalão cobre, é provàvelmente porque se torna o mercado da pimenta, da canela, do gengibre, da noz, da maça, e o tráfico das especiarias anda conexo àquêles dois metais. Explicar-se-ia assim igualmente a passagem todos os anos por Takedda, a mina de cobre, da caravana do Cairo a Mali.

Dos lados do Oceano Índico, a expansão do comércio marítimo chinês, tão intensa precisamente durante os séculos XIII e XIV, acentuava a primazia, quando não a fundava, da circulação da prata. Os juncos chineses não se limitaram então a açambarcar a parte de leão do trato da Malásia, freqüentavam regularmente - Malabar e Cambaia e vieram traficar ao gôlfo Pérsico e às portas do Mar Roxo. Ora a economia chinesa é fundamentalmente, do ponto de vista do comércio internacional, uma bomba aspirante da prata e das especiarias, de fortíssima potência, distribuindo em compensação o ouro, a sêda, a porcelana. E' natural que o Egito, cuja economia está tão ligada às economias do vasto oceano, alinhasse monetàriamente com as condições que o alastrar da atividade mercantil chinesa impusera ou fortificara.

No século XIV, dissemos há pouco, o cobre de Takedda seguia a dorso de camelo para o Egito. Desvio anormal do escoamento lógico dêste metal. Não é a "fome" de cobre, como a fome de sal, uma das constantes preocupações que trabalham os reinos negros? Ora o cobre, só das minas do Sus e Dar'a e da mina saariana pode ir saciar esta violenta necessidade, uma vez que nenhuns jazigos há na Guiné. Por isso, no século XV a corrente inverter-se-á: é agora de Alexandria que segue para o mundo negro, pela escala de Tuate, o cobre do Império Bizantino. Os cristãos que vão comprar especiarias a Alexandria podem fàcilmente descarregar no pôrto egípcio prata e cobre. A carta portuguêsa de 1511 documenta a chegada ao Egito de cobre proveniente de Veneza (ou antes, da Europa central e reexportado pela cidade do Adriático), bem como a sua reexpedição juntamente com as especiarias, os panos de algodão da India e os bijoux, para os reinos negros do Níger.

Exportando para Takedda e Mali os produtos da indústria têxtil egípcia e indú, e uma parte do cobre que os europeus the vendiam, os mercadores do Cairo e de Alexandria podiam com- 
prar nos mercados sudaneses escravos, âmbar, plumas de avestruz, e até ouro.

Por que não admitir, na verdade, que o metal amarelo continuava a afluir ao Egito, embora aqui se não sinta mais a mesma necessidade? Os negros que faziam a peregrinação a Meca passando, é escusado dizê-lo, pelo Cairo, e não devemos subestimar" o seu número, que é que podiam levar consigo de mais prático para pagar as despesas da viagem e estadia, senão ouro? Desde o século XIII, os reis mandingas fizeram a peregrinação à cidade santa. O imperador Gongo Mussa, acompanhado de um séquito numeroso, em 1323, levou consigo tal carregamento de ouro que no Cairo a razão dêste para a prata baixou consideràvelmente. A meio do século XV, o veneziano Cà da Mosto - e um veneziano devia estar bem ao par destas questões - relata que o ouro do Sudão ocidental chega ao Egito pela via de Kukya. Em 1511, um testemunho ainda mais preciso. Os portuguêses estão senhores do Oceano Indico, interessam-se forçosamente pelo comércio do Levante e têm necessidade de se informar àcêrca da situação econômica do Egito. No resumo das informações recolhidas que foi enviado para Lisboa, lê-se que todos os 6 meses chegam ao Cairo duas cáfilas carregadas de ouro, vindas de Tacrur (= Sudão ocidental) pela via do Fezzam: o metal amarelo que trazem é em grande cópia.

Como explicar, nestas condições bem mais complexas do que a princípio se suspeitaria, o abandôno da cunhagem do ouro no Egito? Alinhamento do sistema monetário egípcio pelas condições de comércio internacional prevalecentes no Oceano Indico: tal foi talvez a fôrça determinante da transformação? Parece inegável, por outro lado, que o ouro sudanês que continua a entrar no Egito é em parte comprado pelos cristãos; as galés venezianas, genovesas e catalãs reintroduzem-no parcialmente no mercado egípcio sob a forma de espécies de cunho italiano. Haverá talvez ainda que fazer intervir a Lei de Gresham: a moeda de ouro teria sido expulsa da circulação pelas moedas de prata e de cobre, sendo objeto de entescuramento, em parte pelo menos (468).

Afinal, a análise do problema inicial conduziu tão só a pôr outros problemas, em vez de fechar por uma resolução. Seja como fôr, esța discussão põe bem em relêvo uma das funções do ouro do Sudão na história econômica mundial.

VITORINO DE MAGALHÃES GODINHO do "Centre National de la Recherche Scientifique", Paris.

(468). - Uma análise mais desenvolvida desta evolução egípcia será dada na nossa obra em preparação L'économie de l'empire portugais XVe-XVIe siècles. 


\title{
BIBLIOGRAFIA
}

\author{
A. - FONTES
}

\section{a) - Fontes narrativas e descritivas.}

IBNE HÁUCAL, Description de l'Afrique (cêrca de 950). Tradução De Slane (Journal Asiatique, 1842).

EL-BEKRI, Description de l'Afrique septentrionale (1068), Tradução De Slane. Paris, 1859; nova ed. 1913.

EDRICI, Géographie (1154). Trad. A. Jaubert, Paris, 2 tomos, 1836; Description de l'Afrique et de l'Espagne. Trad. Dozy e De Goeje, Leyde, 1866.

ABU HAMID AL-ANDALUSI AL-GHARNATI, Tuhfat al-Albab wa -nuhbat al-a'gab (1162) .Trad. G. Ferrand (Journal Asiatique, 1925, n.'s 206-207).

DIMASHQUI, Cosmographie (cêrca de 1280). Em M A A E A, tomo IV. ABULFEDA, Géographie (cêrca de 1315). Em M C A E A, tomo IV. GIOVANNI BOCCACCIO, Relaçâo da viagem de Nicoloso de Recco e Andrea dei Gorbizzi ás Canárias (1341). Texto latino no vol. III, tomo I, das Memórias do Congresso do mundo português, 1940 (acompanhado da tradução italiana de Guido Pó; outra trad. italiana, de Rinaldo Gaddeo, em Le Navigazioni Atlantiche). Trad. portuguêsa no tomo I dos Documentos sôbre a expansão portuguêsa.

IBNE FADL ALLAH AL'OMARI, Massalik el Absar fi Mamalik el Amsar (1342-1349). Trad. Gaudefroy-Demombynes, Paris, 1927.

IBNE BATUTA, Voyages (1353-1354). Trad. Defrèmery e B. R. Sanguinetti, tomo IV, Paris, 1922 .

IBNE KHALDUN, Histoire des Berbéres (2a. metade do século XIV). Trad. De Slane, 3 tomos, Argel 1852-1856. Fragmentos em M C A E A, tomo IV.

AL KABUWI (1413). Fragmentos em M C A E A, tomo IV.

MAKRIZI, Traité des monnaies musulmanes (entre 1415 e 1420), trad. Silvestre de Sacy. Paris, 1797.

PIERRE BONTIER e JEAN LE VERRIER, Historia del Primer Descubrimiento y Conquista de las Canarias (entre 1420 e 1430). Trad. castelhana de Pedro Ramirez, Santa Cruz de Tenerife, 1847.

0 original francês foi pela primiera vez dado à estampa no século XVII: Histoire de la première découverte et conqueste des Canaries faite dés l'an 1402 par Massire Jean de Béthencourt, chambellan du Roy Charles VI. Paris, Jean de Heuqueville, 1680. Em 1874 Gabriel Gravier editou um manuscrito de cêrca de 1482 (Le Canarien. Rouen); Pierre Margry deu mais tarde uma edição de outro manuscrito datável de entre 1420 e 1430 (La conquête et les Conquérants des iles Canaries. Paris 1896).

ANTONIO MALFANTE, Carta escrita de Tuate (1447). Original e trad. em La Roncière, La découverte de l'Afrique, tomo I. 
ALVISE DE CÀ DA MOSTO, Navigazioni (1455-1456). Ed. Rinaldo Caddeo, Milão 1929. Trad. Sebastião Trigoso, Lisboa, 1867 (contém alguns erros); reproduzida, correta, e pela primeira vez largamente anotada, no tomo III dos Documentos sôbre a expansẫo portuguêsa, Lisboa, 1956. O texto da ed. Caddeo vem reproduzido em Silva Marques, Descobrimentos Portuguêses, com nova tradução portuguêsa. Texto de uma cópia quatrocentista editado pela Academia Portuguêsa de História, Viagens de Luis de Cadamosto e de Pedro de Sintra, Lisboa, 1948.

GOMES EANES DE ZURARA, Crônica da Guiné (1453-1465). Ed. Visconde de Santarém. Paris, 1841; ed. José de Bragança, Pòrto, 2 tomos, 1937.

DIOGO GOMES e MARTIM BEHAIM, De prima iuentione Guinee. De insulis primo iuentis in mar oceano ocidentis (Viagens até 1462; redação de entre 1485 e depois de 1496). In $O M a-$ nuscrito Valentim Fernandes, ed. Bensaúde-Baião, Lisboa, 1940. Trad. Gatriel Pereira no vol. I dos Documentos sôbre a Expansẫo.

HIERONYMUS MUNZER, De inuentione Africae maritimae et occidentalis uidelicet Geneae per Infantem Heinricum Portugalliae (entre 1494 e 1508). Texto latino e trad. em Basílio de Vasconcelos, "Itinerário" do Dr. Jerônimo Munzer, Coimbra 1932 .

Este livro he de rotear, (roteiro do último quartel do século XV). Em O Manuscrito de Valentim Fernandes.

VALENTIM FERNANDES, A Descriçã de Cepta por sua costa de Mauritania e Ethiopia pellos nomes modernos proseguindo as vezes algumas cousas do sartâo da terra firme $(1507$; baseado, no que se refere ao Sáara, nas observações de João Rodrigues, entre 1493 e 1506). Das Ilhas do Mar Oceano (1506) - Em O Manuscrito de Valentim Fernandes.

DUARTE PACHECO PEREIRA, Esmeraldo de Situ Orbis (entre 1505 e 1520). Ed. Epifânio Dias, Lisboa 1905.

Sumayro das cartas da Imdia dafonso dalboquerque e outros, que trouxe gonçalo de sequeira (1511). Em Cartas de Afonso de Albuquerque, tomo I, p. 438, Lisboa, 1884.

JOÃO LEÃO-O-AFRICANO, Description de l'Afrique tierce partie du monde (1526). Trad. Jean Temporal (1556), 2a. ed., Paris, 1830 .

Monumenta Cartographica Africae et Aegypti. Tomo IV, Cairo, 19351937.

b) . - Fontes cartográficas.

Os mapas do século XIV e comêço do século XV estão reproduzidos em M C A E A, tomo 1V, Cairo, 1935-1937; e alguns também em La Roncière, La découverte de l'Afrique.

Uma carta portuguêsa anônima de circa 1471 - publicada por Fontoura da Costa, Lisboa, 1937.

Segundo A. Cortesão, êste mapa não é de feitura portuguêsa, c a sua data é de alguns anos posterior à aventada por F. da Costa. Por comodidade, no texto referimo-lo sempre pelo título que the deu o seu editor. 
B. - Estudos

ALBERTINI (EUGènE), L'Empire Romain. Paris, 2a. ed. 1936.

ALBER'TINI (E.), MARÇAIS (G.) e YVER (G.), L'Afrique du Nord française dans l'histoire. Paris, 1937.

BARGĖS (ABBE'), Memoire sur les relations commerciales de Tlemcen avec le Soudan sous les règnes des Beni Zeiyan (Revue de l'Orient, de l'algérie et des Colonies, tomo XIII, pp. 337-348). Paris, 1853.

BERNARD (AUGUSTIN), Afrique Septentrionale et Occidentale Deuxième Partie: Sahara - Afrique Occidentale (Géographie Universelle, dirigida por La Blache e L. Gallois, tomo XI, 2a. parte). Paris, 1939 .

Bovilu (E. W.), Caravans of the Old Sahara - An Introduction to the History of the Western Soudan. Londres, 1933.

BRAUDEL (FERNAND), De l'or du Soudan d̀ l'argent d'Amérique. Em Annales-Économies, Sociétés, Civilisations, Ano $\mathrm{I}$, n.: $1,1946$.

La Méditerranée et le monde méditerranéen à l'époque de Philippe II. Paris, 1949.

BROSSET (D.), La saline d'Idjil (Afrique Française - Renseignements coloniaux et documents, XLIII, n. ${ }^{\circ} 11$, pp. 259-265, novembro, 1933).

BRUNSCHWICG (R.), La Berbérie orientale sous les Hafsides. Paris, 2 vols. $1940-1947$.

Un texte arabe du IXe siècle intéressant le Fezzân (Revue Africaine, t. LXXXIX, $10^{\circ}$ e $20^{\circ}$ trimestres 1945, pp. 21-25) .

CAPOT-REY (ROBERT), Géographie de la circulation sur les continents. Paris, 1946.

Le nomadisme pastoral dans le Sahara francais (Travaux de l'Institut de Recherches Sahariennes, t. I), 1942.

La morphologie de l'Erg Occidental (Travaux de l'Institut de Recherches Sahariennes, t. II, pp. 104), 1943.

L'Edeyen de Mourzouk (Idem, t. IV, pp. 67-109), 1947.

Exploration de l'Erg Oriental (Idem, idem, pp. 181-187). 1947. L'exploration du Fezzân (Cahiers Ch. de Foucauld, vol. 11, pp. 26-45).

Le Sahara Français. Paris, 1953.

CARCOPINO (JEROME), Le Maroc antique. Paris, 1943.

CAUVET (GASTON), L'oued in Rhar - Essai sur l'hydraulique au Tidikelt (Cahiers Ch. de Foucauld, vol. 2, pp. 73-85).

CHASSELOUP-LAUBAT, L'expédition alpine française du Hoggar 1935 (Cahiers Ch. de Foucaul, vol. 2, pp. 53-71).

COLIN (G. S.), Des Juifs nomades retrouvés dans le Sahara marocain au XVIe siècle (Mélanges d'études luso-marocains dédiées à la mémoire de David Lopes et Pierre de Cénival, pp. 51-66). Lisboa e Paris, 1945.

CRONE, (R. G.), The Voyages of Cadamosto. Londres (Hakluyt Society), 1937.

COUDRAY (A.), Relations commerciales de Tlemcem avec le Sahara et le Soudan (Bulletin de la Société de Géographie d'Alger, 2..$^{\circ}$ année, pp. 229-253 e 422-430), 1897.

DE BOUARD (MICHEL), Sur l'évolution monétaire de l'Égypte médiévale (L'Égypte contemporaine, Revue de la Société Fouad Ier d'économie politique, de statistique et de législation, t. XXX, pp. 427-459), 1939 . 
DELAFOSSE (MAURICE), Haut-Sénégal-Niger. Tome Ile - L'Histoire. Paris, 1912.

Relations du Maroc et du Soudan à travers les âges (Hespérís, 1924, pp. 153-174).

DESPOIS (JEAN), L'Afrique du Nord francaise. Paris, 1949.

Géographie et histoire (L'Information historique, IIe annéé, $n .^{\circ} 4$, septembre-octobre, 1947).

DUBIEF (JEAN), Les vents de sable dans le Sahara Central (Travaux de l'Institut de Recherches Sahariennes, $t$. II, pp. 11-35), 1943.

Une mission au Sahara Occidental (idem, idem, 199-203).

Les pluies au Sahara Central (idem, t. IV, pp. 7-23), 1947.

Découvertes préhistoriques et archéologiques dans le Sahara central (idem, idem, pp. 189-191).

EYDOUX (HENRI-PAUL), L'Homme et le Sahara. Paris, 1943.

FURON (RAYMOND), Manuel de Préhistoire générale. Paris, 1939.

GADEN (H.), Les salines d'Aoulil (Revue du monde muslman, vol. XII, pp. 436-443), Paris, 1910.

GAUTIER (EMILE-FELIX), Le Sahara. Paris, 1928.

L'or du Soudan dans l'histoire (Annales d'histoire economique et sociale, vol. VII, pp. 113-123), 1935.

Anciennes voies du commerce transsaharien (Geografiska Annaler, t. XVII, Mélanges Sven Hedin, pp. 550-562), Stokholm, 1935.

Moeurs et coutumes des Musulmans. Paris, 1937.

Le Passé de l'Afrique du Nord, Paris, 1937.

L'Afrique blanche. Paris, 1939.

GODDE (HENRI), Le Tassili des Ajiers (Cahiers Ch. de Foucauld, vol. II, pp. 3-15).

GSELL (STEPHANE), Histoire ancienne de l'Afrique du Nord, t. I.

GRUVEL (A.) e CHUDEAU (R.), A travers la Manritanie Occidentale - Volume Premier: Parties générale et économique. Paris, 1909 .

JULIEN (CHARLES ANDRE'), Histoire de l'Afrique du Nord. Paris, 1931 .

KILLIAN (CONRAD), Expédition 1943 - Air et Ténéré (Travaux de l'Institut de Recherches scientifiques, t. III, pp. 73-86), 1945.

LA CHAPELLE (T. de), Esquisse d'une histoire du Sahara Occidental (Hespéris, 1939, pp. 35-95) .

LAMBERT (ROGER), Les salines de Téguidda-n'Tessoum (Bulletin du Comité d'Études historiques et scientifiques de l'Afrique Occidentale Française, t. XVIII, n. ${ }^{\circ} \mathrm{s} 2-3$, abril-setembro, 1937).

LA PRIMAUDÁIE (ELIE de), Le commerce et la navigation de l'Algérie avant la conquête française. Paris, 1860.

LA RONCIÉRE (CHARLES DE), La découverte de l'Áfrique au Moyen-Âge - I L'intérieur, II - Le périple du continent. Cairo, 1924-1925.

Histoire de la découverte de la terre, Paris, 1938.

LEHURAUX (COMMANDANT), Las origines des oasis du Tidikelt et du Bas-Touat (Travaux de l'l. de R. S., t. II, pp. 105-120), 1943.

LELUBRE (MAURICE), Les grands traits géologiques de l'Ahaggár (idem, idem, pp. 55-68).

LESCHI (LOUIS), Rome et les nomades (Travaux de l'Institut de R. S. I., pp. 48 ss.), 1942. 
LHOTE (HENRI), Les Touaregs du Hoggar. Paris, 1944.

Les salines de Teguidda-n'Tisamt ( $L a$ Terre et la Vie, III n. ${ }^{\circ} 12$, pp. 727-735), 1933.

Contribution à l'étude des Touaregs soudanais. No Bulletin de l'Institut Français d'Afrique Noire, 1955, n. ${ }^{\circ} \mathrm{s} 3-4$, pp. 334-369.

LOMBARD (MAURICE), L'or musulman du VIle au Xle siècle (Annales-Economies, Sociétés, Civilisations, $20^{\circ}$ année, $1947, \mathrm{pp}$. 143-160).

Or, argent et cuivre dans l'Égypte du Moyen-Âge (idem, idem, pp. 239-240).

LUCAS, Considérations sur l'ethnique maure. No Journal de la So. citété des Africanistes, I, 1931, pp. 151-194.

MAGNO DE CASTILHO (ALEXANDRE), Descripçâo e roteiro da costa ocidental de Africa. Tomo I, Lisboa, 1866.

MAIRE (Dr. R.) e VOLKANSKY (M.), Le passage du Sahara central central au Sahara méridional (zone sahélo-saharienne) entre l'Adrar des Ifoghas et l'Air (Travaux de l'I. de R. S., t. III, pp. 131-135), 1945 .

MARCAIS (GEORGES), La Berbérie musulmane et l'Orient au Moyen-Âge, Paris, 1946.

MARTIN (A. G. P.), Les oasis sahariennes (Gourara, Touat, Tidikelt). Argel, 1908 .

Quatre siècles d'histoire marocaine. Au Sahara de 1504

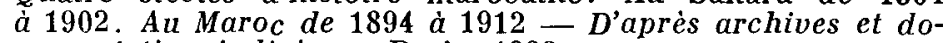
cumentation indigènes. Paris, 1923.

MASSIGNON (LOUIS), Le Maroc dans les premières années du XVIe siècle - Tableau géographique d'après Léon l'Africain. Argel; 1908.

MAUNY (R.), L'Afrique Occidentale d'après les anteurs arabes anciens, 666-977. (Notes Africaines, n. 40, Outubro, 1948).

Itinéraires sahariens anciens (Bulletin de correspondance saharien, n. ${ }^{\circ}$, pp. 8-17, Dakar, julho 1948).

L'expédition marocaine d'Oudane vers 1543-1544. No Bul'letin de l'Institut Français d'Afrique Noire, tomo XI, n.'s 1-2, 1949 , pp. $129-140$.

Les Puniques et l'Afrique noire occidentale. Tune, 1951. Notes d'Histoire et d'Archéologie sur Azougui, Chinguetti et Ouadane. No Bulletin de l'Institut Français d'Afrique Noire, 1955, n. ${ }^{\circ}$ s 1-2, pp. 142-162.

MERCADIER (Lt.), Les pistes moutonnières de l'Ahnet (Travaux de l'l. de $R$. S., t. III, pp. 151-159), 1945.

Mission scientifique du Fezzân (Travaux de l'I. de R. S., t. III, pp. 161-191), 1945.

MOREL (M. H.), Remarques sur la vie mentale et les gestes des Touaregs de l'A haggar. (Idem, t. IV, pp. 127-144), 1947.

MONOD (THEODORE), L'Adrar Ahnet - Contribution à l'étude archéologique d'un district saharien. Paris, 1932.

Compte rendu sommaire de la deuxiéme partie d'une mission au Sahara Occidental (Bulletin du Muséum, 2a. série, t. VII, n. 3 , pp. 311-315), 1936.

Sur la constitution géologique de l'Adrar mauritanien (Comptes rendus des séandes de l'Académie des Sciences, t. 205, p. 74, séance du 5 Juillet, 1937).

Notes hypsométriques sur le Sahara Occidental (Bulletin du Comité d'Études Historiques et Scientifiques de l'AOF, XXI, n. 3 , 1938, pp. 329-344, 1 carte). 
Gravnres, peintures et inscriptiones rupestres (Contributions à l'étude du Sahara Occidental, fasciculo I). Paris, 1938. Notes botaniques sur le Sahara Occidental et ses confins sahéliens (no volume coletivo $L a$ vie dans la région désertique nord-tropicale de l'ancien Monde, Paris, 1938, pp. 351-374) .

Taghazza, la ville en sel gemme (La Nature, maio, 1938, pp. 289-296) .

Nouvelles remarques sur Teghaza (Bulletin de l'Institut Français d'Afrique Noire, II, 1940, pp. 248-250 e gravuras IV-VI) .

Sur quelques détails d'architecture africaine (Acta Tropica, t. 4, pp. 342-345), 1947.

Nouvelles figurations rupestres de chars du Sahara Occidental (em colaboração com o capitão Couneille).

Sur quelques constructions anciennes du Sahara Occidental (memória arqueológico-bibliográfica apresentada à Société de Géographie et d'Archeologie de la Province d'Oran, 1948). Le Sahara étanche ou. "perméable"? (Cahiers Ch. de Faucould, n. 11 , pp. 96-103), 1948.

La structure du Sahara atlantique (Travaux de l'I. de R. S., t. III, pp. 27-55), 1945.

MONOD (Th.) e CENIVAL (PIERRE de), Description de la côte d'Afrique de Ceuta au Sénégal par Valentim Fernandes. Paris, 1938 .

MONTAGNE (ROBERT), La limite du Maroc et du Sahara atlantique (Hespéris, 1930, pp. 111-118).

La Civilisation du Désert. Paris, 1947.

NICOLAS (FRANCIS), La transhumance chez les Iullemmeden de l'Est (Travaux de l'I. de R. S., t. IV, pp. 111-126), 1947.

PERES (HENRI), Relations entre la Tafilalet et le Soudan à travers le Sahara, du XIIe au XIVe siècle (Mélanges offerts $\dot{a} E . F$. Gautier, Tours, 1938).

PERRET (ROBERT), Les gravures rupestres et les peintures $\dot{a}$ l'ocre du Sahara français et du Fezzân - historique et description sommaire (Cahiers Ch. de Foucauld, n. ${ }^{\circ}$ 10, pp. 81-95).

Le progrés des connaissances relatives au Sahara (Idem, n. ${ }^{\circ}$ 3-4, pp. 145-168).

POTTIER (RENE'), Histoire du Sahara. Paris, 1947.

RICARD (ROBERT), Les Portugais et le Sahara atlantique au XVe siècle (Hespéris, 1930, pp. 97-110).

Les "alquitões" des nomadas sahariens (Hespéris. 1937, p. 135) .

RODD (FRANCIS RENNELL), People of the Veil-Being an Account of the Habits, Organization and History of the wandering Tuareg Tribes which inhabit the Mountains of Air or Asben in the Central Sahara. Londres, 1926.

ROGET (Capne. J.), Fêtes religieuses au Gourara (Travaux de l'I. de R. S., t. III) .

ROY (A.), Vestiges de Takedda, ancienne capitale des Igdalen, centre minier et caravanier de l'Air au XIVe siècle (Notes Africaines, n. ${ }^{\circ} 29$, pp. 5-7), 1946.

RUHLMANN (ARMAND), Deux gravures rupestres de style géométrique troluvées aux Ait Saadane (Maroc saharien) (Travaux de l'I. de R. S., t. III, pp. 141-150), 1945 .

SIGROARTH (Lt. GEORGES), La vie économique dans l'oasis de Djanet (idem, t. IV, pp. 175-180), 1947. 


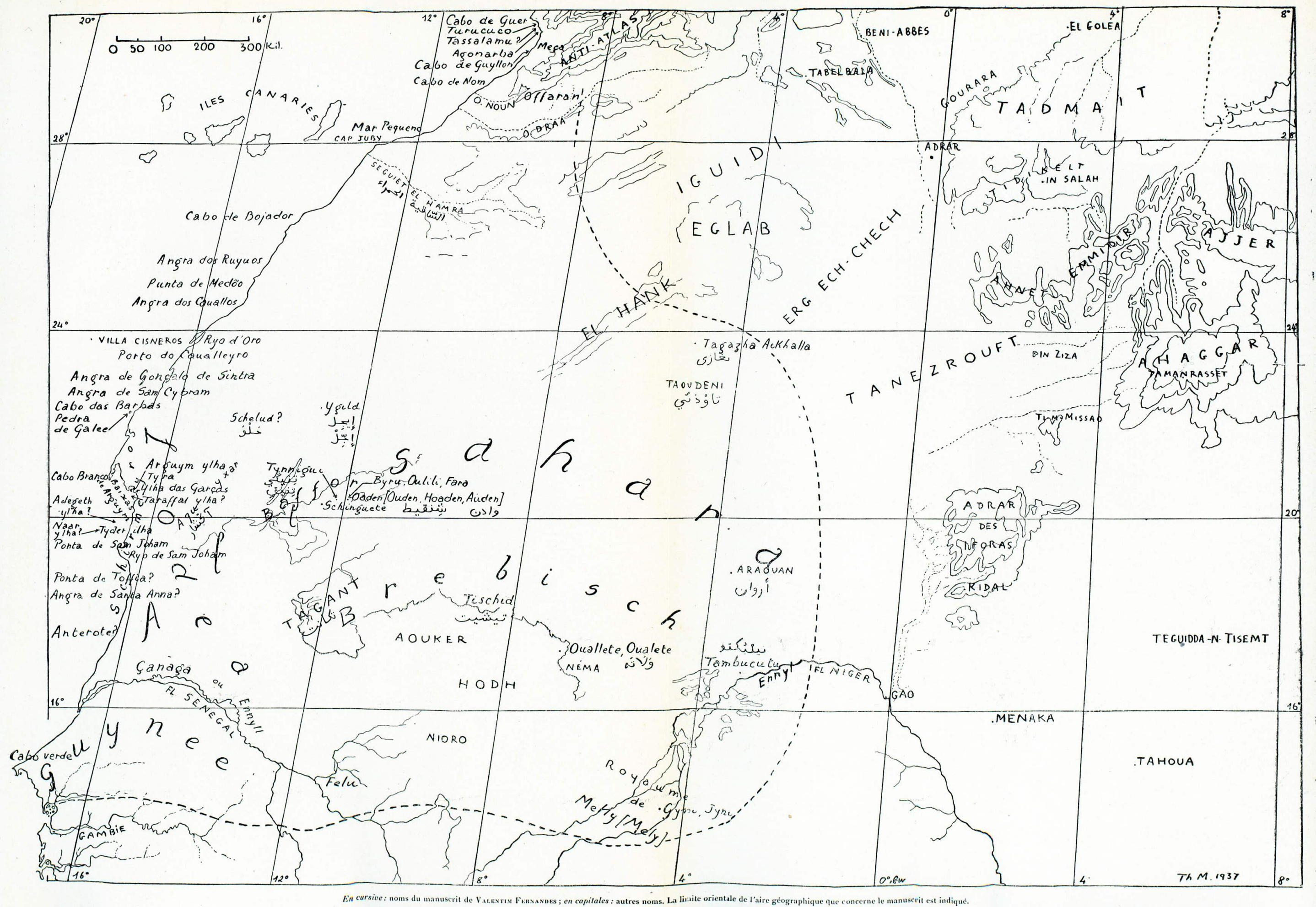


TERRASSE (HENRI), Note sur les ruines de Sijilmassa (Revue Africaine, 1936, pp. 368-369). Histoire du Maroc. Tomo I, Paris, 1950.

TRICART (J.), Carte géomorphologique du delta du Sénégal. No Bulletin de l'Association de Géographes Français, maio-junho 1955 , pp. 98-117.

URVOY (Y.), Histoire des populations du Soudan Central. Paris, 1936 .

VAUFREY (R.), L'Áge de l'Art Rupestre Nord-Africain 1936.

$$
\text { c. - CARTOGRAFia }
$$

GRANDIDIER (E.) (direção de), Atlas des Colonies Françaises. Paris, 1934.

MARQUART - Em M C A E A, tomo IV.

MEUNIER (A.), Carte physique de l'Afrique Occidentale Française.

SAINT-MARTIN (VIVIEN DE) e SCHRADER, Atlas de Géographie Universelle.

MAUNY (R.), L'Afrique d'après Plolémée, vers 141 a. c. 